PNNL-17684

RPP-PLAN-38191, Rev. 0

U.S. DEPARTMENT OF

(1.6) ENERGY

Prepared for the U.S. Department of Energy

under Contract DE-AC05-76RL01830

\title{
Science Road Map for Phase 2 of the Tank-Farm Vadose Zone Program
}

\author{
JM Zachara \\ MD Freshley \\ Pacific Northwest National Laboratory \\ FM Mann \\ CH2M Hill Hanford Group
}

August 2008 


\title{
DISCLAIMER
}

This report was prepared as an account of work sponsored by an agency of the United States Government. Neither the United States Government nor any agency thereof, nor Battelle Memorial Institute, nor any of their employees, makes any warranty, express or implied, or assumes any legal liability or responsibility for the accuracy, completeness, or usefulness of any information, apparatus, product, or process disclosed, or represents that its use would not infringe privately owned rights. Reference herein to any specific commercial product, process, or service by trade name, trademark, manufacturer, or otherwise does not necessarily constitute or imply its endorsement, recommendation, or favoring by the United States Government or any agency thereof, or Battelle Memorial Institute. The views and opinions of authors expressed herein do not necessarily state or reflect those of the United States Government or any agency thereof.

\author{
PACIFIC NORTHWEST NATIONAL LABORATORY \\ operated by \\ BATTELLE \\ for the \\ UNITED STATES DEPARTMENT OF ENERGY \\ under Contract DE-ACO5-76RL01830
}

Printed in the United States of America
Available to DOE and DOE contractors from the
Office of Scientific and Technical Information,
P.O. Box 62, Oak Ridge, TN 37831-0062;
ph: (865) 576-8401
fax: (865) 5765728
email: reports@adonis.osti.gov

\author{
Available to the public from the National Technical Information Service, \\ U.S. Department of Commerce, 5285 Port Royal Rd., Springfield, VA 22161 \\ ph: (800) 553-6847 \\ fax: (703) 605-6900 \\ email: orders@nits.fedworld.gov \\ online ordering: http://www.ntis.gov/ordering.htm
}


PNNL-17684

RPP-PLAN-38191, Rev. 0

\title{
Science Road Map for Phase 2 of the Tank-Farm Vadose Zone Program
}

\author{
JM Zachara \\ MD Freshley \\ Pacific Northwest National Laboratory \\ FM Mann \\ CH2M Hill Hanford Group
}

August 2008

Prepared for

The U.S. Department of Energy

Under Contract DE-AC05-76RL01830

Pacific Northwest National Laboratory

Richland, Washington 99352 


\section{Summary}

Phase 1 of the Tank-Farm Vadose Zone Program (TFVZP) developed information on the nature and extent of vadose zone contamination in the tank farms through field studies, laboratory analyses and experiments, and historical data searches; assembled data and performed tank-farm risk analysis; and initiated interim corrective actions to lessen the impacts of tank leak contaminants. Pacific Northwest National Laboratory scientists and external collaborators at universities and U.S. Department of Energy user facilities sampled and analyzed contaminant plumes. They also performed more detailed, hypothesis-driven scientific studies that led to markedly improved conceptual models of tank waste migration in the vadose zone. This interdisciplinary expertise has led to significant scientific innovation in the cleanup program at the Hanford Site. These types of activities will continue during Phase 2 of the TFVZP to refine and expand scientific understanding of the subsurface beneath tank farms, especially of water movement, residual waste leaching, and contaminant transport. Subsurface science studies of various types will be performed to enable interim, corrective, and mitigation measures to be implemented effectively and efficiently and to develop system-level understanding and assessment capabilities to enable sound tank-farm closure.

The science and technology (S\&T) efforts described in this document include focused research to develop knowledge and advanced capabilities to accomplish tank-farm closure, which will consist of actions to reduce human health and environmental threats posed by a hazardous waste treatment, storage, and/or disposal facilities. Close alignment and partnership with the TFVZP will be maintained through the course of S\&T activities to verify that resulting scientific data and derived information, updated conceptual and numeric models, and technology meet first order needs of the tank-farm closure mission that involves corrective and mitigation actions as well as scientifically rigorous closure assessments that credibly describe and forecast risk. A goal of the TFVZP is to develop data and understanding to support decisions for remediation and closure of the tank farms. The emphasis during Phase 1 was to close specific knowledge gaps and to develop understanding to predict the transport, fate, and mitigation of inground tank waste contaminants and the leaching behavior of residual tank waste. During Phase 2, efforts will shift to developing data and scientific understanding to assist with remediation decisions and design and to predict the long-term behavior of vadose zone contaminants and residual tank waste.

Research activities (see Table ES-1) are described in this roadmap to address source-term identification and contaminant release, recharge and moisture flow, contaminant mobility and transport, and tank-farm closure technologies. For each of these technical areas, a series of research topics are proposed, including a description of need, the approach, outcome and benefit, and an approximate schedule to link the activity to tank-farm closure. The schedule assumption for closing the first tank farm is 2019. Multiple products will accrue during the time-frame for each activity, but the end date represents the final insertion point for the research results. Integrating tank-farm activities with other vadose zone and groundwater work ongoing at the Hanford Site is also described. 
Table S-1. Summary of Science and Technology Activities Supporting Phase 2 Tank-Farm Closure.

\begin{tabular}{|c|c|c|c|}
\hline $\begin{array}{c}\text { Title / Problem } \\
\text { Definition }\end{array}$ & Approach & Outcome and Benefit & Schedule \\
\hline \multicolumn{4}{|c|}{ Source Term Identification and Contaminant Release } \\
\hline $\begin{array}{l}\text { Source Term } \\
\text { Identification } \\
\text { (Section 3.1) }\end{array}$ & $\begin{array}{l}\text { Isotope methods based on mass spectrometry } \\
\text { measurements were developed and applied during } \\
\text { Phase 1. High-precision U isotopic measurements will } \\
\text { be used to delineate contributions from complex waste } \\
\text { sources. Analytical methods will be further developed } \\
\text { for isotopic quantification of mobile oxyanion fission } \\
\text { products, including } \mathrm{Ru}, \mathrm{Se} \text {, and Mo. }\end{array}$ & $\begin{array}{l}\text { This research will develop, improve, and } \\
\text { apply high-resolution isotopic methods for } \\
\text { attribution of } U \text { and fission products in } \\
\text { vadose zone and groundwater plumes to } \\
\text { known leak and disposal events. The } \\
\text { relative mobility of specific isotopic } \\
\text { contaminants will be determined in different } \\
\text { waste streams to provide input for } \\
\text { remediation decisions. }\end{array}$ & $\begin{array}{l}\text { Methods } \\
\text { Development: } \\
\text { Start Date: } 2009 \\
\text { End Date: } 2011 \\
\text { Application; } \\
\text { Start Date: } 2011 \\
\text { End Date: } 2019\end{array}$ \\
\hline $\begin{array}{l}\text { Tank Chemistry } \\
\text { Evolution } \\
\text { (Section 3.2) }\end{array}$ & $\begin{array}{l}\text { Predicting long-term contaminant release from residual } \\
\text { tank waste depends on scientific understanding of post- } \\
\text { closure tank-chemistry evolution. Contaminant } \\
\text { releases will be controlled by the integrated effects of } \\
\text { tank chemistry and diffusive or advective moisture } \\
\text { flux. Characterization methods previously applied to } \\
\text { residual tank wastes will be augmented with more } \\
\text { sensitive microscopic and spectroscopic techniques to } \\
\text { identify host mineral phases controlling contaminant } \\
\text { release and their properties. Laboratory studies will be } \\
\text { performed to investigate sequestration mechanisms and } \\
\text { release rates of contaminants and the effects of } \\
\text { chemical composition change on mineral stability and } \\
\text { contaminant release. The potential long-term effects } \\
\text { of microbial activity on contaminant distribution, } \\
\text { speciation, and release rates will also be investigated. }\end{array}$ & $\begin{array}{l}\text { This research will provide new analytical } \\
\text { and experimental information on the } \\
\text { mineralogic residence of tank waste } \\
\text { contaminants and the effects of microbial } \\
\text { activity on tank waste chemistry and } \\
\text { contaminant release. The new analytical and } \\
\text { experimental information generated will } \\
\text { provide insights on contaminant } \\
\text { sequestration and release over the long time } \\
\text { frames of tank-farm closure. }\end{array}$ & $\begin{array}{l}\text { Start Date: } 2009 \\
\text { End Date: } 2016\end{array}$ \\
\hline
\end{tabular}


Table S.1 (Contd)

\begin{tabular}{|c|c|c|c|}
\hline $\begin{array}{l}\text { Title / Problem } \\
\text { Definition }\end{array}$ & Approach & Outcome and Benefit & Schedule \\
\hline $\begin{array}{l}\text { Source Term } \\
\text { Release } \\
\text { (Section } 3.3 \text { ) }\end{array}$ & $\begin{array}{l}\text { The technical basis of contaminant release models for } \\
\text { residual tank wastes after closure will depend on the } \\
\text { robustness of the experimental database (contaminant } \\
\text { release over time, water flux rates, and evolving } \\
\text { chemical conditions) and process-descriptive } \\
\text { relationships and parameters controlling release. An } \\
\text { experimental kinetic database on contaminant release } \\
\text { from residual tank waste will be developed to serve as } \\
\text { a basis for integrated model development, calibration, } \\
\text { and confirmation. Tank-farm closure decisions will } \\
\text { strongly rely on robust, scientifically credible } \\
\text { computer simulations of potential contaminant fluxes } \\
\text { based on experimental data collected over a relevant } \\
\text { range of conditions. }\end{array}$ & $\begin{array}{l}\text { This research will provide experimental data } \\
\text { to support the development of defensible } \\
\text { models for source-term release calculations. } \\
\text { The resulting mechanistic models will be } \\
\text { more scientifically defensible and less } \\
\text { conservative, which may reduce the costs of } \\
\text { tank-farm closure. }\end{array}$ & $\begin{array}{l}\text { Start Date: } 2011 \\
\text { End Date: } 2018\end{array}$ \\
\hline \multicolumn{4}{|c|}{ Recharge and Moisture Flow } \\
\hline $\begin{array}{l}\text { Operational } \\
\text { Recharge-1943 } \\
\text { to Barrier } \\
\text { (Section 4.1.1) }\end{array}$ & $\begin{array}{l}\text { Research is needed to estimate Hanford recharge at } \\
\text { specific tank-farm locations such as } \mathrm{C} \text { Farm for } \\
\text { undisturbed and operational conditions. Recharge for } \\
\text { undisturbed conditions will be estimated with multi- } \\
\text { tracer isotopic methods, including }{ }^{2} \mathrm{D} /{ }^{18} \mathrm{O}, \mathrm{Cl},{ }^{36} \mathrm{Cl}, \mathrm{I} \text {, } \\
\mathrm{U}, \mathrm{Sr}, \mathrm{Br}, \mathrm{SO}_{4} \text {, and chlorofluorocarbons. Recharge for } \\
\text { operational conditions will be determined by direct } \\
\text { measurements and by soil physics model calculations, } \\
\text { including thermal and air phases and the impacts of } \\
\text { gravel covers with varying concentrations and layering } \\
\text { of fines. }\end{array}$ & $\begin{array}{l}\text { This research will provide improved and } \\
\text { validated estimates of recharge obtained by } \\
\text { multiple methods for different tank farms. } \\
\text { These methods will negate the need to use } \\
\text { one assumed, less accurate value. } \\
\text { Assessments specific to tank farms will } \\
\text { reduce uncertainties in recharge-driven } \\
\text { contaminant migration. }\end{array}$ & $\begin{array}{l}\text { Start Date: } 2009 \\
\text { End Date: } 2014\end{array}$ \\
\hline
\end{tabular}


Table S.1 (Contd)

\begin{tabular}{|c|c|c|c|}
\hline $\begin{array}{l}\text { Title / Problem } \\
\text { Definition }\end{array}$ & Approach & Outcome and Benefit & Schedule \\
\hline $\begin{array}{l}\text { Recharge } \\
\text { Through Barriers } \\
\text { (Section 4.1.2) }\end{array}$ & $\begin{array}{l}\text { Effective surface barrier design requires approaches to } \\
\text { estimate the depth of barrier effectiveness and } \\
\text { performance metrics such as impact on recharge. A } \\
\text { combination of field measurements and modeling is } \\
\text { needed to verify that tank-farm barrier designs will } \\
\text { perform as desired over realistic time frames. }\end{array}$ & $\begin{array}{l}\text { This research will provide the scientific basis } \\
\text { for surface barrier design and improved } \\
\text { recharge rates for use in performance } \\
\text { assessments supporting tank-farm closure } \\
\text { decisions. These results will reduce } \\
\text { uncertainties in the extent of recharge-driven } \\
\text { contaminant migration. }\end{array}$ & $\begin{array}{l}\text { Start Date: } 2009 \\
\text { End Date: } 2014\end{array}$ \\
\hline $\begin{array}{l}\text { Evaluation of } \\
\text { Post-Closure } \\
\text { Recharge } \\
\text { (Section 4.1.3) }\end{array}$ & $\begin{array}{l}\text { Uncertainty in long-term recharge will impact tank- } \\
\text { farm closure decisions. A framework for identifying } \\
\text { and evaluating future recharge scenarios will be } \\
\text { established and linked with predictions of global } \\
\text { climate change and impacts on local weather. }\end{array}$ & $\begin{array}{l}\text { This research will provide the scientific basis } \\
\text { for assessing the impacts of climate change } \\
\text { on long-term recharge through surface } \\
\text { barriers. These results will help make } \\
\text { certain that desired environmental protection } \\
\text { and function are cost effective. }\end{array}$ & $\begin{array}{l}\text { Start Date: } 2009 \\
\text { End Date: } 2014\end{array}$ \\
\hline $\begin{array}{l}\text { Geophysical } \\
\text { Approaches for } \\
\text { 3-D Geofacies } \\
\text { Characterization } \\
\text { (Section 4.2.1) }\end{array}$ & $\begin{array}{l}\text { The spectral gamma logging system (SGLS) provides a } \\
\text { wealth of detailed, vertically resolved data on natural } \\
\text { isotopes known to be correlated with geologic facies } \\
\text { and properties controlling moisture retention and flow. } \\
\text { Research will develop Hanford-specific correlations } \\
\text { between these natural isotopes and subsurface } \\
\text { geohydrologic properties for more accurate and } \\
\text { resolved subsurface property determination. }\end{array}$ & $\begin{array}{l}\text { This research will provide the necessary } \\
\text { relationships to identify thin silt and sand } \\
\text { layers that cause lateral spreading of tank } \\
\text { waste solutions and increased physical } \\
\text { retardation in the vadose zone. The result } \\
\text { will be improved quantitative ability to } \\
\text { model moisture content and migration to } \\
\text { develop effective tank-farm closure } \\
\text { strategies. }\end{array}$ & $\begin{array}{l}\text { Start Date: } 2009 \\
\text { End Date: } 2014\end{array}$ \\
\hline $\begin{array}{l}\text { Heterogeneities } \\
\text { and Lateral Flow } \\
\text { (Section 4.2.2) }\end{array}$ & $\begin{array}{l}\text { Further testing and development are needed for } \\
\text { approaches to quantify the impact of heterogeneities } \\
\text { and moisture-dependent anisotropy on lateral flow and } \\
\text { transport. Scientific studies will quantify hydraulic } \\
\text { properties and their spatial variation for detailed } \\
\text { modeling of 3-D vadose zone flow and contaminant } \\
\text { transport. }\end{array}$ & $\begin{array}{l}\text { This research will provide data and detailed } \\
\text { models of lateral flow and transport. Results } \\
\text { will be used to improve the design of tank- } \\
\text { farm remediation and closure actions. }\end{array}$ & $\begin{array}{l}\text { Start Date: } 2009 \\
\text { End Date: } 2014\end{array}$ \\
\hline
\end{tabular}


Table S.1 (Contd)

\begin{tabular}{|c|c|c|c|}
\hline $\begin{array}{l}\text { Title / Problem } \\
\text { Definition }\end{array}$ & Approach & Outcome and Benefit & Schedule \\
\hline $\begin{array}{l}\text { Moisture Flow } \\
\text { Under Dry } \\
\text { Conditions } \\
(4.2 .3)\end{array}$ & $\begin{array}{l}\text { Engineered barriers are expected to reduce recharge } \\
\text { rates in closed tank farms by an order of magnitude or } \\
\text { more, reducing the amount of water to levels that are } \\
\text { difficult to measure. Laboratory experiments will be } \\
\text { used to develop new relationships between hydraulic } \\
\text { conductivity and water content in low moisture } \\
\text { regimes. }\end{array}$ & $\begin{array}{l}\text { This research will resolve basic issues such } \\
\text { as direction and rate of water movement and } \\
\text { controls on unsaturated flow under dry } \\
\text { conditions and where high salt } \\
\text { concentrations exist. These relationships } \\
\text { will be used in detailed models of post- } \\
\text { closure conditions within tank farms to } \\
\text { improve the design of tank-farm remediation } \\
\text { and closure actions. }\end{array}$ & $\begin{array}{l}\text { Start Date: } 2012 \\
\text { End Date: } 2016\end{array}$ \\
\hline \multicolumn{4}{|c|}{ Contaminant Mobility and Transport } \\
\hline \multicolumn{4}{|c|}{ Key Contaminants of Concern for Tank-Farm Closure (Section 5.5.1) } \\
\hline $\begin{array}{l}\text { Uranium } \\
\text { (Section 5.1.1) }\end{array}$ & $\begin{array}{l}\text { Uranium is a key contaminant in tank farms where first } \\
\text { cycle metal waste was accidentally released to the } \\
\text { vadose zone. A generalized model for U will be } \\
\text { developed based on experimental measurements that } \\
\text { can predict the solid-liquid distribution of U(VI) and } \\
\text { its reactive transport over a variety of waste, } \\
\text { geochemical, and hydrologic conditions present in } \\
\text { tank-farm vadose zones. }\end{array}$ & $\begin{array}{l}\text { This research will yield a generalized model } \\
\text { and reaction parameters to predict aqueous } \\
\text { concentrations and the migration velocity of } \\
\text { contaminant } U(V I) \text { in different waste } \\
\text { streams and diverse tank-farm sediments. } \\
\text { Understanding and predicting contaminant } \\
\text { mobility will directly impact tank-farm } \\
\text { remediation design and closure actions. }\end{array}$ & $\begin{array}{l}\text { Start Date: } 2009 \\
\text { End Date: } 2011\end{array}$ \\
\hline
\end{tabular}


Table S.1 (Contd)

\begin{tabular}{|c|c|c|c|}
\hline $\begin{array}{l}\text { Title / Problem } \\
\text { Definition }\end{array}$ & Approach & Outcome and Benefit & Schedule \\
\hline $\begin{array}{l}\text { Anions } \\
\text { (Section 5.1.2) }\end{array}$ & $\begin{array}{l}\text { Anionic chemical and fission product contaminants are } \\
\text { the most mobile tank waste contaminants in the vadose } \\
\text { zone and are major risk drivers. Laboratory } \\
\text { experimental measurements will focus on the fate of } \\
\text { fission product and process anions }\left({ }^{99} \mathrm{Tc},{ }^{129} \mathrm{I}, \mathrm{Cr} \text {, various }\right. \\
\left.\text { isotopes } \mathrm{Ru} \text {, various isotopes } \mathrm{Mo},{ }^{79} \mathrm{Se} \text {, and possibly }{ }^{60} \mathrm{Co}\right) \text { that } \\
\text { are mobile, drive risk, and are indicative of waste } \\
\text { sources. Quantitative information will be developed } \\
\text { on anion mobility for enhanced interpretation of waste } \\
\text { plume migration velocities, future groundwater } \\
\text { concentrations, and overall risk protection. }\end{array}$ & $\begin{array}{l}\text { This research will provide quantitative } \\
\text { information on anion mobility for enhanced } \\
\text { interpretation of waste plume migration. } \\
\text { Understanding and predicting contaminant } \\
\text { mobility will directly impact tank-farm } \\
\text { remediation design and closure actions. }\end{array}$ & $\begin{array}{l}\text { Start Date: } 2010 \\
\text { End Date: } 2014\end{array}$ \\
\hline $\begin{array}{l}\text { In Situ } \\
\text { Measurements of } \\
\text { Migration } \\
\text { Velocities and } \\
\text { Flux } \\
\text { (Section 5.2) }\end{array}$ & $\begin{array}{l}\text { Characterization studies of tank-farm plumes in the } \\
\text { vadose zone are static, based on sediments collected at } \\
\text { a single point in time. The migration rates and fluxes } \\
\text { of mobile tank waste constituents in the deep vadose } \\
\text { zone are unknown and currently estimated with fate } \\
\text { and transport models. High-density geophysical data } \\
\text { sets will be obtained for key tank waste plumes that } \\
\text { display potential to yield information on migration } \\
\text { velocity. The data will be obtained through mining of } \\
\text { historical measurements or by new and systematic } \\
\text { repeat logging. }\end{array}$ & $\begin{array}{l}\text { This research will yield direct measurements } \\
\text { of migration velocity in the deep vadose } \\
\text { zone to allow improved modeling of } \\
\text { contaminant arrival times and concentrations } \\
\text { at regulatory boundaries. Such } \\
\text { measurements will allow better remediation } \\
\text { and closure decisions. }\end{array}$ & $\begin{array}{l}\text { Start Date: } 2010 \\
\text { End Date: } 2013\end{array}$ \\
\hline
\end{tabular}


Table S.1 (Contd)

\begin{tabular}{|l|l|l|l||}
\hline $\begin{array}{l}\text { Title / Problem } \\
\text { Definition }\end{array}$ & \multicolumn{1}{|c||}{ Approach } & \multicolumn{1}{c||}{ Outcome and Benefit } \\
\hline $\begin{array}{l}\text { Coupled } \\
\text { Reactions } \\
\text { (Section 5.3) }\end{array}$ & $\begin{array}{l}\text { Ion exchange and precipitation/dissolution reactions } \\
\text { have not been sufficiently quantified and } \\
\text { parameterized to allow predictions of ion exchange and } \\
\text { precipitation fronts relative to mobile anion fronts } \\
\text { (e.g., Tc and } \mathrm{NO}_{3} \text { ) in the field as required for reactive } \\
\text { transport analysis. }\end{array}$ & $\begin{array}{l}\text { This research will provide models to predict } \\
\text { evolving porewater composition in } \\
\text { sediments of different types required to } \\
\text { describe geochemical reactions and interpret } \\
\text { chromatographic profiles of vadose zone } \\
\text { tank waste plumes. These data, insights, and } \\
\text { models will facilitate decisions regarding } \\
\text { whether deep vadose zone plumes can and } \\
\text { should be remediated or left in place. }\end{array}$ \\
& $\begin{array}{l}\text { Laboratory investigations using (contaminated and } \\
\text { uncontaminated) deep vadose zone sediments will } \\
\text { identify and parameterize processes controlling } \\
\text { porewater composition under unsaturated conditions to } \\
\text { the point of predicting important sediment-tank waste } \\
\text { scenarios. Coupled hydrologic-geochemical processes } \\
\text { will be characterized in deep vadose zone sediments } \\
\text { impacted by tank waste, and key reactive transport } \\
\text { properties will be measured. }\end{array}$ & \\
\hline
\end{tabular}


Table S.1 (Contd)

\begin{tabular}{|c|c|c|c|}
\hline $\begin{array}{l}\text { Title / Problem } \\
\text { Definition }\end{array}$ & Approach & Outcome and Benefit & Schedule \\
\hline $\begin{array}{l}\text { Mass Transfer } \\
\text { and Slow } \\
\text { Reactions } \\
\text { (Section 5.4) }\end{array}$ & $\begin{array}{l}\text { Most discharges of tank waste to the vadose zone } \\
\text { occurred many years ago (e.g., 1950-1970) during } \\
\text { active waste management and Hanford Site production } \\
\text { periods. These tank wastes have resided in the vadose } \\
\text { zone for an extended period of time, allowing } \\
\text { sediment-waste geochemical reactions that are } \\
\text { kinetically slow and slow diffusion into relatively } \\
\text { inaccessible micropores and microfractures in } \\
\text { sediment lithic fragments. Increasing evidence } \\
\text { suggests that a sizable inventory of tank waste } \\
\text { residuals reside in these domains that exhibit unique } \\
\text { reactivity. Research will be performed to determine } \\
\text { the role of mass transfer in limiting the release of } \\
\text { sorbed tank waste contaminants from impacted } \\
\text { sediments. The research will identify the rates of } \\
\text { contaminant exchange between sediment particles and } \\
\text { unsaturated porewaters and particle physicochemical } \\
\text { properties controlling non-reactive and reactive mass } \\
\text { transfer. }\end{array}$ & $\begin{array}{l}\text { This research will provide mass transfer } \\
\text { process models that can be linked with } \\
\text { reactive transport simulators. Mass transfer } \\
\text { and slow reactions may increase the } \\
\text { retardation of many contaminants and smear } \\
\text { their arrival times at groundwater. This } \\
\text { research will identify the conditions under } \\
\text { which these processes operate and develop } \\
\text { models to accurately simulate their effect on } \\
\text { vadose zone contaminant transport. }\end{array}$ & $\begin{array}{l}\text { Start Date: } 2013 \\
\text { End Date: } 2017\end{array}$ \\
\hline
\end{tabular}


Table S.1 (Contd)

\begin{tabular}{|c|c|c|c|}
\hline $\begin{array}{l}\text { Title / Problem } \\
\text { Definition }\end{array}$ & Approach & Outcome and Benefit & Schedule \\
\hline $\begin{array}{l}\text { Microbiologic } \\
\text { Transformations } \\
\text { and Reactions } \\
\text { (Section 5.5) }\end{array}$ & $\begin{array}{l}\text { Viable and functional radiation- and desiccation- } \\
\text { resistant microorganisms were observed in the SX-108 } \\
\text { plume. Consequently, it is probable that } \\
\text { microorganisms will play an important role in } \\
\text { influencing the speciation, stability, and migration } \\
\text { behavior of vadose zone tank waste contaminants } \\
\text { before and after closure. New research will build on } \\
\text { past studies performed in the SX tank farm and other } \\
\text { uncontaminated vadose zone sediments to identify } \\
\text { prominent organism types present, evaluate their } \\
\text { current activity, and assess their future potential to } \\
\text { influence the mobility of key tank-waste constituents } \\
\text { [Tc(VII), Cr(VI), and U(VI)]. }\end{array}$ & $\begin{array}{l}\text { This research will provide needed insights } \\
\text { on the unknown influence of subsurface } \\
\text { microorganisms on tank-farm contaminant } \\
\text { migration and in situ sequestration. Both } \\
\text { positive and detrimental impacts might } \\
\text { occur. }\end{array}$ & $\begin{array}{l}\text { Start Date: } 2013 \\
\text { End Date: } 2017\end{array}$ \\
\hline $\begin{array}{l}\text { Multi-Process } \\
\text { Data Integration } \\
\text { (Section 5.6) }\end{array}$ & $\begin{array}{l}\text { Hydrologic, geochemical, and microbiologic processes } \\
\text { couple in complex ways to control contaminant } \\
\text { migration in the vadose zone. Sometimes, the } \\
\text { collective effects of these processes are } \\
\text { counterintuitive because the individual processes } \\
\text { exhibit non-linear behavior, and conceptual models of } \\
\text { vadose zone contaminant transport may be incorrect. } \\
\text { Individual hydrologic and geochemical process models } \\
\text { will be improved to be fully consistent with field } \\
\text { conceptual models and laboratory-defined behavior, } \\
\text { field characterization data, and other important tank- } \\
\text { farm observations (such as borehole geophysics). } \\
\text { Process models of liquid migration and reactive } \\
\text { transport will be tested and confirmed by comparisons } \\
\text { with field data and moisture profiles. }\end{array}$ & $\begin{array}{l}\text { This research will provide an efficient, } \\
\text { systems-level simulation framework that } \\
\text { integrates the best information on the } \\
\text { unsaturated system and reactive transport } \\
\text { processes with a goal of reducing the } \\
\text { uncertainty in projections of future } \\
\text { contaminant transport. The resulting model } \\
\text { will more accurately forecast future } \\
\text { migration for various scenarios associated } \\
\text { with tank-farm closure. }\end{array}$ & $\begin{array}{l}\text { Start Date: } 2013 \\
\text { End Date: } 2017\end{array}$ \\
\hline
\end{tabular}


Table S.1 (Contd)

\begin{tabular}{|c|c|c|c|}
\hline $\begin{array}{l}\text { Title / Problem } \\
\text { Definition }\end{array}$ & Approach & Outcome and Benefit & Schedule \\
\hline \multicolumn{4}{|c|}{ Tank-Farm Closure Technologies } \\
\hline $\begin{array}{l}\text { Subsurface } \\
\text { Access and } \\
\text { Sampling } \\
\text { Methods } \\
\text { (Section 6.1) }\end{array}$ & $\begin{array}{l}\text { Drilling operations within tank farms require special } \\
\text { consideration of contamination and radiation } \\
\text { protection. Recent developments have focused on a } \\
\text { hydraulic hammer that pushes small-diameter casing to } \\
120 \text {-ft depth (deeper at some locations) and at angles. } \\
\text { It will recover multiple samples. There are significant } \\
\text { limitations to this method that include depth of } \\
\text { penetration, small sample size that is inadequate for all } \\
\text { but total compositional analysis, and inability to } \\
\text { retrieve highly contaminated samples. New and/or } \\
\text { improved methods for subsurface access will be } \\
\text { identified or developed and tested in the field. }\end{array}$ & $\begin{array}{l}\text { This research will yield workable } \\
\text { technologies that improve subsurface access } \\
\text { and recovery at a cost below that of } \\
\text { boreholes for robust characterization needed } \\
\text { to support tank-farm closure. }\end{array}$ & $\begin{array}{l}\text { Start Date: } 2009 \\
\text { End Date: } 2012\end{array}$ \\
\hline $\begin{array}{l}\text { Field } \\
\text { Measurements of } \\
\text { Contaminants of } \\
\text { Concern } \\
\text { (Section 6.2) }\end{array}$ & $\begin{array}{l}\text { The measurement of subsurface concentrations of } \\
\text { contaminants of concern (COC) is vital to tank-farm } \\
\text { characterization, remediation, monitoring, and closure. } \\
\text { Automated, sensor-based measurement systems that } \\
\text { are solar powered and directly relay results by wireless } \\
\text { communication will be developed for key tank-farm } \\
\text { COC (beginning first with }{ }^{99} \mathrm{Tc} \text { ). }\end{array}$ & $\begin{array}{l}\text { This research will provide new in situ } \\
\text { measurement capabilities to support robust } \\
\text { site characterization and the development of } \\
\text { sound monitoring systems for tank-farm } \\
\text { remediation and closure. }\end{array}$ & $\begin{array}{l}\text { Start Date: } 2009 \\
\text { End Date: } 2019\end{array}$ \\
\hline
\end{tabular}


Table S.1 (Contd)

\begin{tabular}{|c|c|c|c|}
\hline $\begin{array}{l}\text { Title / Problem } \\
\text { Definition }\end{array}$ & Approach & Outcome and Benefit & Schedule \\
\hline $\begin{array}{l}\text { Geophysical } \\
\text { Approaches for } \\
\text { 3-D Plume } \\
\text { Delineation } \\
\text { (Section 6.3) }\end{array}$ & $\begin{array}{l}\text { Vadose zone contaminant plumes have traditionally } \\
\text { been characterized by borehole sampling, which } \\
\text { provides 1-D representations (in the case of a single } \\
\text { borehole). Subsurface Geophysical Exploration } \\
\text { (SGE), also known as High Resolution Resistivity } \\
\text { (HRR) has recently been deployed to delineate vadose } \\
\text { zone plumes and has shown promise for 3-D plume } \\
\text { mapping. Inadequate understanding of infrastructure } \\
\text { effects and geochemical and hydrophysical properties } \\
\text { controlling geophysical response, however, prevent } \\
\text { sound measurement interpretation. Research will be } \\
\text { performed to resolve scientific issues pertaining to } \\
\text { application of SGE/HRR for accurate mapping of } \\
\text { subsurface contaminant plumes. Controlled laboratory } \\
\text { experiments will provide a basis for distinguishing } \\
\text { between sediment texture and mineralogy, moisture } \\
\text { content, and fluid composition effects. Establishing } \\
\text { fundamental relationships between tank waste } \\
\text { compositions, vadose zone hydrophysical properties } \\
\text { and moisture content, and electrical parameters will } \\
\text { allow quantitative use of geophysical measurements. }\end{array}$ & $\begin{array}{l}\text { This research will provide fundamental } \\
\text { relationships between tank waste } \\
\text { compositions, vadose zone hydrophysical } \\
\text { properties and moisture content, and } \\
\text { electrical parameters for quantitative use of } \\
\text { geophysical measurements. More accurate } \\
\text { and economical design of remedies such as } \\
\text { surface barriers to support closure will be } \\
\text { enabled. }\end{array}$ & $\begin{array}{l}\text { Start Date: } 2009 \\
\text { End Date: } 2012\end{array}$ \\
\hline
\end{tabular}


Table S.1 (Contd)

\begin{tabular}{|c|c|c|c|}
\hline $\begin{array}{l}\text { Title / Problem } \\
\text { Definition }\end{array}$ & Approach & Outcome and Benefit & Schedule \\
\hline $\begin{array}{l}\text { Waste Form } \\
\text { Hydrology } \\
\text { (Section 6.6) }\end{array}$ & $\begin{array}{l}\text { Single-shell tanks (SSTs) that are closed will consist of } \\
\text { residual tank waste surrounded by engineered } \\
\text { materials such as grouts. The hydraulic and } \\
\text { geochemical properties of the grout material will affect } \\
\text { the release of contaminants from the residual tank } \\
\text { wastes. Iterative activities between engineering and } \\
\text { science organizations working on grout stabilization of } \\
\text { the SSTs will be required to establish a conceptual } \\
\text { hydrophysical model of a closed tank that can be } \\
\text { parameterized to estimate water and contaminant } \\
\text { fluxes that will evolve over the long term. }\end{array}$ & $\begin{array}{l}\text { This research will result in accurate } \\
\text { descriptions of waste-form behavior and } \\
\text { contaminant release. Closure decisions will } \\
\text { rely heavily on system-scale computer } \\
\text { models to forecast future behavior, including } \\
\text { the isolated residual tank waste form. } \\
\text { Defensible characterization of the properties } \\
\text { of stabilized residual tank wastes will allow } \\
\text { credible predictions of future contaminant } \\
\text { release. }\end{array}$ & $\begin{array}{l}\text { Start Date: } 2014 \\
\text { End Date: } 2019\end{array}$ \\
\hline
\end{tabular}


Table S.1 (Contd)

\begin{tabular}{|c|c|c|c|}
\hline $\begin{array}{l}\text { Title / Problem } \\
\text { Definition }\end{array}$ & Approach & Outcome and Benefit & Schedule \\
\hline $\begin{array}{l}\text { Improved Surface } \\
\text { Barriers } \\
\text { (Section 6.7) }\end{array}$ & $\begin{array}{l}\text { Tank-farm closure surface barriers will have stringent } \\
\text { requirements for reduction of recharge, design life, and } \\
\text { long-term performance after the design life is reached } \\
\text { that have not yet been specified. Research will be } \\
\text { performed on the existing Hanford Prototype Barrier } \\
\text { by integrating new and existing geophysical } \\
\text { measurements and will be interpreted with state-of-the- } \\
\text { art geophysical models to develop the best possible } \\
\text { understanding of performance. }\end{array}$ & $\begin{array}{l}\text { This research will yield improvements to } \\
\text { surface barrier design in terms of materials, } \\
\text { layering, slope, etc. These results will } \\
\text { provide confidence that residual tank wastes } \\
\text { can be effectively isolated in the subsurface } \\
\text { to prevent or reduce future impacts. }\end{array}$ & $\begin{array}{l}\text { Start Date: } 2011 \\
\text { End Date: } 2015\end{array}$ \\
\hline $\begin{array}{l}\text { Improved } \\
\text { Computer Codes } \\
\text { (Section 6.8) }\end{array}$ & $\begin{array}{l}\text { A variety of computer codes will be improved and } \\
\text { parameterized as part of research leading to successful } \\
\text { tank-farm closure. These will include ones describing } \\
\text { contaminant geochemical and biogeochemical } \\
\text { interactions and transformations; moisture migration, } \\
\text { barrier performance, and reactive transport; residual } \\
\text { waste evolution and source term release; and } \\
\text { relationships between geophysical measurements, } \\
\text { hydrologic properties, and porewater compositions. } \\
\text { Science-based computer codes that have high potential } \\
\text { to be used for tank-farm closure assessments will be } \\
\text { identified early in the closure processes and thoroughly } \\
\text { tested for use in the regulatory arena. }\end{array}$ & $\begin{array}{l}\text { This research will produce validated, } \\
\text { scientifically based models combined with } \\
\text { the most current and rigorous databases and } \\
\text { process-descriptive parameters. These } \\
\text { models will reduce the uncertainty in tank- } \\
\text { farm closure assessments and improve the } \\
\text { acceptance of closure decisions. }\end{array}$ & $\begin{array}{l}\text { Start Date: } 2012 \\
\text { End Date: } 2017\end{array}$ \\
\hline
\end{tabular}


Page Intentionally Blank 


\section{Acronyms}

ASCR Advanced Scientific Computing Research

BER Biological and Environmental Research

COC Contaminant(s) of concern

CPC Central Plateau Contractor

DOE Department of Energy

ERSD Environmental Remediation Sciences Division

ERSP Environmental Remediation Science Program

ES\&H Environmental, safety, and health

EMSL Environmental Molecular Sciences Laboratory

FIR Field Investigation Report

HRR High resolution resistivity

ICP-MS Inductively coupled plasma mass spectrometer

ICP-OES Inductively coupled plasma optical emission spectrometer

IFC Hanford Integrated Field Challenge

LBNL Lawrence Berkley National Laboratory

MCL Maximum concentration level

MCNP Monte Carlo Neutron -Photon

NMR Nuclear magnetic resonance

ORP Office of River Protection

PNNL Pacific Northwest National Laboratory

PUF Pressurized unsaturated flow

QA Quality assurance

QC Quality control

RACL Radiochemistry and Actinide Chemistry Laboratory

RCRA Resource Conservation and Recovery Act

RPL Radiochemical Processing Laboratory (325 Building)

S\&T Science and technology

SC DOE's Office of Science

SEM/EDS Scanning electron microscopy/energy dispersive spectrometry

SFA Scientific focus area program

SGE Subsurface geophysical exploration

SGLS Spectral gamma logging system

SST Single-shell tank

SST-PA Single-Shell Tank Performance Assessment 
STOMP Subsurface Transport Over Multiple Phases

TFVZP Tank-Farm Vadose Zone Program

TOC Tank Operations Contractor

TSD Treatment, storage, and/or disposal

UFA Unsaturated flow apparatus

UHV Ultra high vacuum

XRD X-ray diffraction 


\section{Acknowledgments}

This report was written with primary support from the Tank Farm Vadose Zone Project led by CH2M Hill Hanford Group, Inc., in support of the U.S. Department of Energy (DOE) Office of River Protection (ORP); and secondary support from DOE's Office of Science, Environmental Remediation Sciences Division (ERSD). 


\section{Page Intentionally Blank}




\section{Contents}

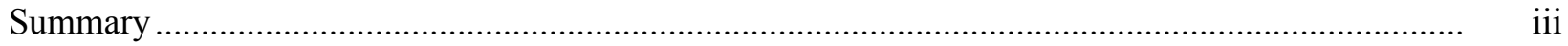



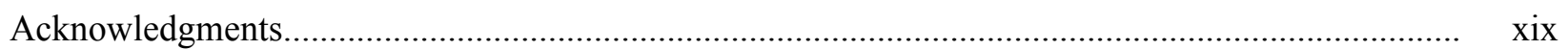

$1.0 \quad$ Introduction................................................................................................................. 1.1

$1.1 \quad$ Purpose of the Report .................................................................................................... 1.1

1.2 Hanford Site Background .................................................................................. 1.1

1.3 Tank-Farm Vadose Zone Program .............................................................................. 1.2

1.4 Structure of the Report................................................................................................ 1.3

$2.0 \quad$ Science and Technology Approach ……………………............................................... 2.1

$2.1 \quad$ Wrap-Around Science ……………………………….......................................... 2.1

2.2 Additional Phase 2 Characterization …………………............................................ 2.2



2.4 Facilities and Staff.......................................................................................... 2.4

3.0 Source Term Identification and Contaminant Release ………................................................. 3.1

3.1 Source-Term Identification........................................................................................ 3.1

3.2 Tank Chemistry Evolution................................................................................. 3.2

3.3 Source Term Release ................................................................................................... 3.3

4.0 Recharge and Moisture Flow ……………………..................................................... 4.1

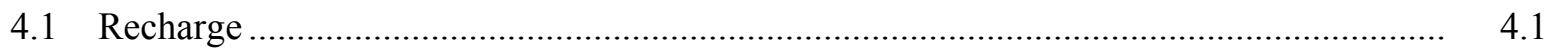

4.1.1 Operational Recharge Before Barrier Emplacement............................................ 4.1

4.1.2 Recharge Through Barriers ................................................................................ 4.2

4.1.3 Evaluation of Post-Closure Recharge ................................................................. 4.3



4.2.1 Geophysical Approaches for 3-D Geofacies Characterization ................................ 4.3

4.2.2 Heterogeneities and Lateral Flow ...................................................................... 4.4

4.2.3 Moisture Flow Under Dry Conditions .............................................................. 4.5

5.0 Contaminant Mobility ................................................................................................ 5.1

5.1 Key Contaminants of Concern for Tank-Farm Closure................................................. 5.1

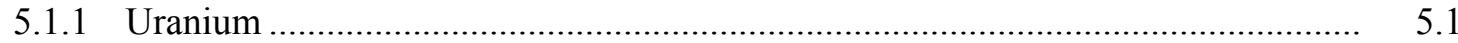



5.2 In Situ Measurements of Migration Velocities and Flux .................................................. 5.3

5.3 Coupled Reactions ................................................................................................ 5.3

5.4 Mass Transfer and Slow Reactions........................................................................... 5.4

5.5 Microbiologic Transformations and Reactions............................................................... 5.5 


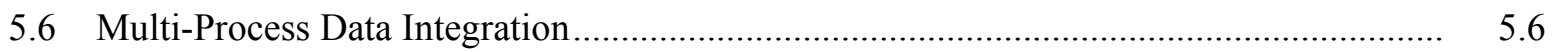

6.0 Tank-Farm Closure Technologies ............................................................................... 6.1

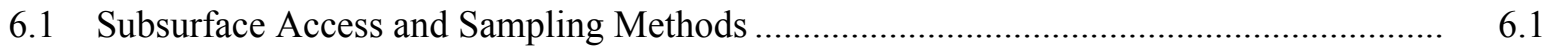



6.3 Geophysical Approaches for 3-D Plume Delineation................................................. 6.2







6.7 Improved Computer Codes ............................................................................................ 6.5

7.0 Integration with Other Hanford Efforts ….........................................................................

7.1 Contractor-Directed Research and Development Activities .......................................... 7.1

7.2 DOE-Directed Research and Development Activities................................................... 7.2

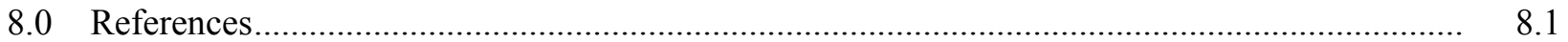




\subsection{Introduction}

\subsection{Purpose of the Report}

This document describes research activities to support Phase 2 of the Hanford Tank-Farm Vadose Zone Program (TFVZP). Such activities include source-term identification and contaminant release, recharge and moisture flow, contaminant mobility and transport, and tank-farm closure technologies. For each of these technical areas, a series of research topics are proposed, including a description of need, the approach, predicted outcome and benefit, and an approximate schedule to link the activity to tank-farm closure, which will consist of actions to reduce human health and environmental threats posed by a hazardous waste treatment, storage, and/or disposal (TSD) facility. Multiple products will accrue during the time-frame for each activity, but the end date represents the final insertion point for the research results. Integrating tank-farm activities with other vadose zone and groundwater work ongoing at the Hanford Site is also described.

Science and technology will support the goals for Phase 2 of the TFVZP to:

- refine and expand scientific understanding of the 200 Area vadose zone, including water movement, residual waste leaching, and contaminant transport developed in Phase 1

- obtain vadose zone data, information, and process-level scientific understanding needed to implement interim, corrective, and mitigation measures effectively and efficiently

- develop requisite system level understanding and credible modeling capabilities for sound tank-farm closure.

\subsection{Hanford Site Background}

The Hanford Site, a facility in the U.S. Department of Energy (DOE) nuclear waste complex, encompasses $\sim 1517$ square kilometers northwest of the city of Richland along the Columbia River in southeastern Washington State. The federal government acquired the site in 1943 to produce plutonium, which was produced until the 1980s. Beginning in the 1990s, DOE has focused on cleaning up the site.

To store radioactive waste, 177 large, underground tanks were constructed at the Hanford Site, 149 of them single-shelled. These single-shell tanks (SSTs) and their associated facilities are grouped into 12 farms. This roadmap focuses on the SSTs and their associated facilities.

Hanford operations released contaminants to the environment. In the early years of plutonium production, airborne releases from the stacks of the separations plants constituted a significant release of radioactive contaminants to the environment. During the years of peak production, the cooling waters for the reactors near the Columbia River became contaminated and were discharged to the river. Policy allowed untreated radioactive waste discharges to the soil from 1943 to 1995 . Over 400 billion gallons of waste (predominately contaminated wastewater) were discharged to the soil. In some cases, tank waste fluids (on the order of 100 million gallons) were intentionally discharged to the ground after cascading through three or more tanks to allow settling of the more radioactive sludge. 
The releases to the environment have resulted in large groundwater plumes extending from both the 200East Area and the 200-West Area. Large areas of the groundwater have concentrations above drinking water standards. The sources of most of the groundwater contamination are mainly large liquid discharges made many decades ago from the separations plants to crib facilities. However, some of the fluids that leaked from the single-shell tanks have reached the groundwater.

\subsection{Tank-Farm Vadose Zone Program}

The TFVZP was established to address

- characterizing the vadose zone impacted by tank-farm releases

- estimating future impacts from those releases

- planning the remediation of tank-farm soils

- implementing simple remediation activities.

Phase 1 of the TFVZP (1998-2008) developed information on the nature and extent of vadose zone contamination in the tank farms through field studies, laboratory analyses and experiments, and historical data searches; assembled data for tank-farm risk models; and performed interim corrective actions to lessen the impacts of tank leak contaminants (DOE ORP, 2008). Pacific Northwest National Laboratory scientists and external collaborators at universities and U.S. Department of Energy user facilities sampled and analyzed contaminant plumes. They also performed more detailed, hypothesis-driven scientific studies. Characterizing the physical, chemical, and geologic attributes of vadose zone tank waste plumes during Phase 1 provided unprecedented advancements in the understanding of the relative mobility of different tank waste constituents and the large influences of geologic structures on water migration and plume character. The importance of small-scale variations in sediment texture on lateral flow of water and contaminants is now recognized from these measurements.

Tank waste contaminants released to the vadose zone have been shown to exhibit a wide range of mobility. Some contaminants have been strongly retarded by adsorption and precipitation reactions (e.g., plutonium, americium, and europium), while others have remained mobile (e.g., technetium and nitrate). Still others show variable, waste-specific behaviors (e.g., cesium, strontium, chromium, and uranium) that are closely tied to the evolving composition of sediment porewater and for chromium and other polyvalent species. There is also a bulk and mineral-surface redox potential. Heat exchange with subsurface sediments lowers the temperature of tank waste released to the vadose zone, and reactions with sediment minerals and secondary mineral precipitation have neutralized the high concentrations of base $\left(\mathrm{OH}^{-}\right)$. Major geochemical features that may potentially affect the mobility of key contaminants of interest in the vadose zone include oxidation state, aqueous speciation, solubility of precipitated forms, and adsorption reactions controlled by mineral surfaces. The findings from Phase 1 of the TFVZP and the contributions of science to resolving key issues are documented in DOE ORP (2008) and a number of literature publications.

A similar approach was used for characterization studies of tank residual waste to support the development of release model(s) for tank-closure assessments. These studies have included waste samples from seven sludge and salt-cake tanks. Because these were the first studies of their kind using residual tank wastes, research has not progressed to the stage of hypothesis-driven research resulting in 
understanding and quantification of controlling processes and mechanisms leading to the development of scientifically credible models of contaminant release. However, certain key cross-cutting chemical properties/behaviors and solid-phase characteristics that control contaminant release have become evident.

Additional characterization studies are needed in Phase 2 to complete the development of a necessary database on the plume behavior of different representative tank waste types. Moreover, approaches need development (e.g., involving statistics, geophysical measurements, and modeling), and scientific studies are required to more rigorously define:

- the in-ground inventory and 3-D spatial and depth distribution of tank waste plumes and the specific distribution of COCs within them

- in situ contaminant flux rates in the deep vadose zone and overall migration velocities for the centers of mass of different tank waste constituents (e.g., $\mathrm{NO}_{3}, \mathrm{Na},{ }^{99} \mathrm{Tc}$, and $\mathrm{Cr}$ ). These data are recognized in Phase 1 Field Investigation Reports (FIR) documents and data-gaps analysis as critically needed information for more accurate risk assessments.

The Initial Single-Shell Tank Performance Assessment (SST-PA; DOE ORP 2005) analyzed the potential long-term impacts of residual wastes remaining after tank-farm closure using current information and concluded that the largest future impact would result from past releases of tank waste to the vadose zone. The projected impacts of residual tank waste remaining after retrieval were 10 times or more below performance objectives. In contrast, impacts from past tank waste releases were projected to exceed performance objectives for all tank farms except $\mathrm{C}$ because of residual ${ }^{99} \mathrm{Tc},{ }^{129} \mathrm{I}$, and $\mathrm{Cr}$ in the vadose zone.

\subsection{Structure of the Report}

Section 1 provides an introduction to the report, while Section 2 describes the scientific approach. The next four sections deal with Source Term Identification and Contaminant Release, Recharge and Moisture Flow, Contaminant Mobility, and Tank-Farm Closure Technologies. For each of the activities defined in the sections, the objectives, approach, benefit, and schedule are described. Section 7 describes integration with other Hanford Site and DOE headquarters activities. 
This page is intentionally blank 


\subsection{Science and Technology Approach}

Tank-farm closure will require that tank waste retrieval is completed, tanks are stabilized, other facilities are decontaminated and decommissioned, contaminated soil is remediated, moisture entering the tank farm is minimized, and impacts are monitored. To support these efforts, the TFVZP will collect and analyze new field and laboratory data as necessary to fully understand water and contaminant distribution and movement in the vadose zone, develop and test models and associated parameter and databases to credibly predict long-term risk and environmental impacts, and establish new technologies to support closure objectives and minimize long-term impacts.

The science and technology (S\&T) efforts described in this document include focused research to develop knowledge and advanced capabilities to accomplish tank-farm closure. Close alignment and partnership with the TFVZP will be maintained through the course of S\&T activities to verify that resulting scientific data and derived information, updated conceptual models, and technology meet first-order needs of the tank-farm closure mission that involve corrective and mitigation actions and scientifically rigorous closure assessments that credibly describe and forecast risk. A common goal of Phase 1 and 2 of the TFVZP is to develop data and understanding to support decisions for remediation and closure of the tank farms. The emphasis during Phase 1 was to close specific knowledge gaps and to develop understanding to predict the transport, fate, and mitigation of in-ground tank waste contaminants and the leaching behavior of residual tank waste. During Phase 2, efforts will shift to developing data and scientific understanding to assist with remediation decisions and design and to predict the long-term behavior of vadose zone contaminants and residual tank waste. In doing so, the research emphasis will shift to cost reduction.

\subsection{Wrap-Around Science}

A three-tiered approach for laboratory analyses was developed in Phase 1 to characterize the behavior of in-ground tank waste contaminants that was approved by the Washington State Department of Ecology. In the first two tiers of this approach, contaminated vadose zone sediment samples collected by the TFVZP were analyzed to determine

- contaminant concentrations in porewaters and sediments

- contaminant chromatographic profiles and apparent in situ distribution coefficients describing retardation

- other relevant physical, chemical, and mineralogic parameters necessary to develop initial conceptual models of contaminant distribution and migration.

The samples included intact cores and grab samples obtained from boreholes through vadose zone waste plumes in the tank farms and sediment samples collected during hydraulic hammer direct-push campaigns.

This approach of an initial characterization phase was necessary to determine the contaminant levels and hazards of the sediment samples before more detailed, hypothesis-driven studies were performed in thirdtier experiments by Pacific Northwest National Laboratory (PNNL) scientists and external collaborators at universities and DOE user facilities. The third-tier studies were termed "wrap-around science" because 
of close association with, and dependence on, the field characterization campaign. The overall objective of the wrap-around science was to understand the underlying chemical and physical processes controlling contaminant transport for key contaminants in specific waste plumes (e.g., ${ }^{137} \mathrm{Cs}$ and $\mathrm{Cr}$ contamination near tank 241-SX-108 and U contamination from tank 241-BX-102). These analyses included determining the valence state of sorbed contaminants [e.g., chromium $(\mathrm{Cr})$ oxidation state as $\mathrm{Cr}^{+3} \mathrm{or}^{+\mathrm{Cr}^{+6}}$ ] using X-ray and laser spectroscopies, identifying the location and binding mechanisms of contaminants on or inside mineral structures using advanced forms of chemical imaging microscopies, and quantifying the release or migration kinetics of specific contaminants from tank-farm sediments during current or future interactions with percolating waters.

A tiered approach was also used for characterization studies of tank residual waste to support the development of release model(s) for tank closure assessments. These studies included waste samples from seven sludge and salt-cake tanks. Because of their high content of radioactive elements, limited number and volume of samples, and high environmental, safety, and health (ES\&H) concern, special characterization methods were adapted to meet the unique requirements of these samples. Initial laboratory measurements (Tier 1) included determination of contaminant inventory and bulk chemical concentrations and quantification of water-leachable contaminants and other waste components. Dissolution experiments of various types evaluated contaminant release by meteoric waters or pore solutions from cementitous grout, a proposed tank waste fill. Select, high-priority wastes were analyzed to identify the controlling processes or mechanism(s) of release of key contaminants (e.g. $\left.{ }^{99} \mathrm{Tc}\right)$. Second tier measurements consisted of X-ray diffraction (XRD) and scanning electron microscopy/energy dispersive spectrometry (SEM/EDS) analyses of the solids to identify reactive and contaminantcontaining solid phases, including Fe- and Al-oxides. Complimentary solubility experiments, selective extractions to identify contaminant host phases, X-ray absorption spectroscopy to determine contaminant molecular speciation, and Mössbauer spectroscopy measurements to determine Fe valence and structural environments were performed on several waste forms to demonstrate their usefulness in advanced conceptual model development.

Because these were the first studies of their kind using residual tank wastes, research has not progressed to the stage of hypothesis-driven research resulting in understanding and quantifying the controlling processes/mechanisms leading to the development of scientifically credible models of contaminant release. However, certain key cross-cutting chemical properties/behaviors and solid-phase characteristics that control contaminant release have become evident. Further research is needed to confirm, resolve, quantify, and understand these cross-cutting features and processes for a fully representative suite of residual wastes and to codify them into semi-empirical, speciation-based thermodynamic and kinetic models. Such a general understanding will allow tanks to be classified into general categories with common chemical and mineralogic characteristics, contaminant release behaviors, and model features and processes. This is an important Phase 2 research goal because complete characterization of all 149 single shell tanks is not practical or economically feasible.

\subsection{Additional Phase 2 Characterization}

Phase 2 tank-farm characterization studies will target specific contaminants, waste and/or hydrologic regimes, geologic facies and structures, and mitigation/closure scenarios where significant scientific uncertainty exists. Conceptual models will be developed for the migration of all representative tank waste 
compositional types based on field sampling in appropriate tank farms and associated analyses of retrieved contaminated sediment.

The first region to be interrogated during Phase 2 of the Resource Conservation and Recovery Act (RCRA) Corrective Action Program is the $\mathrm{C}$ single-shell tank farm and surrounding area, the first singleshell tank farm scheduled for closure. An important scientific issue in this farm is the source of the ${ }^{99} \mathrm{Tc}$ groundwater plume underlying the farm. Several characterization campaigns have been initiated with the goal of identifying a potential source for the contamination, including boreholes near tank C-105, the C152 diversion box, and unplanned releases at 200-E-81 and 200-E-86.

During Phase 2, the first tier of measurements (Tier I) will identify basic chemical properties of the sediments and the identity and concentration of contaminants present. Second tier measurements quantify in situ solid-liquid distribution ratios and develop data to allow correlations between contaminant mobility and sediment hydrophysical and geochemical properties. Tier II measurements may include chemical-dissolution extractions of potentially reactive phases [Fe(III) oxides and carbonates], mineralogic determinations, grain size and hydraulic conductivity, and contaminant desorption or dissolution-rate behavior. Major new objectives of Tier I and II activities will be to:

- apply statistically based sampling strategies and interpretations whenever feasible and practical

- establish relationships between tank waste contaminant concentrations in collected plume sediments analyzed by conventional means and geophysical responses measured at the plume scale by highresolution resistivity (HRR) or subsurface geophysical exploration (SGE).

The final tier of study (Tier III or wrap-around science performed by PNNL and DOE's Office of Science [SC]-funded collaborators) will resolve more detailed questions or hypotheses regarding chemical speciation, mineralogic residence, microscopic and macroscopic transport behavior, and process mechanisms and modeling. These studies will be used to refine and expand the understanding of contaminant transport developed in Phase 1 and obtain data and information needed for tank-farm closure. The detailed studies are described in Sections 3-6 of this roadmap.

\subsection{Data Integration}

Phase 2 of the TFVZP will develop information needed to select and design corrective measures, safety analysis, risk assessments, and permitting. The transfer of scientific understanding and associated data from S\&T investigations to tank-farm applications is an important aspect of the overall process that requires proactive assimilation and digestion of detailed science findings into higher-level, more accessible information. This was accomplished in Phase 1 of the TFVZP by targeted contributions of S\&T findings and modeling to various FIR documents. Multi-process reactive transport models that integrate large amounts of S\&T information and data and that yield results on system behavior were also used for this purpose. Science-based modeling can determine which features and processes are critical to system description or outcome, and which are not. Simplifications in conceptual model complexity and risk assessment model assumptions can increase the transparency of models and their results. For example, S\&T modeling efforts during Phase 1 evaluated the impacts of nonisothermal system behavior on moisture and contaminant migration in the S-SX tank farm. Results demonstrated that a fully coupled heat flow-water transport model did not deliver marked improvements in system description over a 
simpler model that did not explicitly consider temperature effects. An isothermal model was consequently used for risk assessment that yielded considerable cost and time savings.

The issue of lateral moisture and contaminant migration is another example of how S\&T findings and data can be assimilated into models and transferred to the Hanford science and engineering community for widespread application. S\&T efforts during Phase 1 demonstrated that repetitive thin layers of siltsized materials cause lateral spreading of vadose zone moisture under unsaturated conditions, a longobserved, but poorly understood Hanford phenomenon. Coupled laboratory and field studies provided process-level understanding that enabled rigorous new models and associated geohydrologic parameters to be developed that describe this process for Hanford applications. The lateral transport of moisture and contaminants will be a primary consideration in the design of interim and final surface barriers for tankfarm mitigation and closure. S\&T-derived models of lateral flow and site-specific hydrogeologic parameters will be critical tools for surface barrier design in Phase 2.

\subsection{Facilities and Staff}

As in Phase 1, the capabilities of the DOE complex, particularly those at the Pacific Northwest National Laboratory (PNNL) will be utilized in Phase 2. PNNL facilities and capabilities that will be used during Phase 2 include laboratories and staff in the Applied Geology and Geochemistry Group and the Environmental Dynamics and Simulation Groups for conducting radiological ("hot") and non-radiological ("cold") studies. These include laboratories housed in the Radiochemical Processing Laboratory (RPL, 325 Building). Eleven fully equipped, radiologically controlled, wet chemistry laboratories (over 6,000 $\mathrm{ft}^{2}$ ) are available for project research. The laboratories enable batch, column, and flow-through reactor studies of varying scale using tracers and contaminated waters and sediments. The laboratories have $\mathrm{pH}$ meters, automated titrators, balances, ovens, shakers, centrifuges, wet sieving machines, and a controlled atmosphere chamber with desired gas compositions for working with redox and carbonate sensitive samples. The RPL has capabilities and equipment to perform flow-through column experiments under unsaturated moisture conditions, including the unsaturated flow apparatus (UFA) and the patented pressurized unsaturated flow (PUF) apparatus. Laboratory instrumentation includes a Beckman unsaturated flow apparatus, a state-of-the-art Perkin Elmer ELAN DRC II inductively coupled plasma mass spectrometer (ICP-MS) with dynamic reaction cell technology, an ICP-MS attached to a glove box, a Perkin Elmer Optima 3300 DV inductively coupled plasma optical emission spectrometer (ICP-OES), a Scintag X-ray diffractometer with a Peltier thermoelectrically cooled detector and a copper X-ray tube, a Bruker Model S4 Pioneer X-ray fluorometer, a Dionex DX-600 ion chromatograph, a Dionex DX-600 ion chromatograph with a MSQ ${ }^{\mathrm{TM}}$ Plus Mass Spectrometer mass spectrometer, a Micrometrics ASAP 2000 surface area analyzer, a Shimadzu model TOC-V CSN carbon analyzer, three Shimadzu UV-VIS recording spectrophotometers, and four computer-controlled elevated temperature, PUF apparatuses. Radioanalytical instrumentation includes three $60 \%$ efficient intrinsic-germanium gamma detectors, a Wallac model 1415 liquid scintillation counter, and a Wallac 1480 Wizard automated gamma counter. The analytical capabilities housed within the RPL have been used to safely and successfully analyze the most radioactively contaminated samples collected by the TFVZP to date.

PNNL facilities that will also be used for Phase 2 include the Radiochemistry and Actinide Chemistry Laboratory (RACL) in the $331 \mathrm{Bldg}$, which enables batch and flow-cell reactor studies of varying scale using radioactive tracers or contaminated waters and sediments and trace and major element analysis of all derived solutes of either radioactive or non-radioactive character. The laboratory maintains dedicated 
equipment, controlled environment chambers and glove-boxes, and approved radiation work protocols to study uranium, technetium, americium, plutonium, and other tank waste contaminants of concern (COC). Extensive analytical equipment is housed in the RACL, including a counting room with state-of-the-art detectors as well as spectroscopy, chromatography, and other systems for measuring major cations, anions, and trace metals. The laboratory also has capabilities for preparing thin sections with radioactive sample materials that have been extensively applied to sediments contaminated with tank wastes.

The Environmental Molecular Sciences Laboratory (EMSL) is a DOE user facility at PNNL. The facility has advanced capabilities for environmental molecular sciences that have been applied to tank waste samples in a non-dispersable state. Over 135 different instrumental capabilities are present, including an extensive ultra high vacuum (UHV) surface science laboratory with various new-generation electron microscopies; a state-of-the-art optical spectroscopy laboratory for environmental materials; multiple vibrational spectroscopies and microscopies; various scanning probe microscopies; a variable temperature Mössbauer laboratory for iron mineralogy studies; powder, single crystal, and micro X-ray diffraction capabilities with extensive search-match databases; various molecular and ion-beam spectroscopies for microchemical analyses and imaging mineral surface structure and porosity; and mineral analytical and colloid chemical instrumentation. A mass spectrometry center exists for analyzing Hanford microoganisms, and a large nuclear magnetic resonance (NMR) spectrometer facility enables protein characterization, biomolecular studies of different types, and intragrain diffusion studies with tank-farm porous media. In addition, computational hardware and software resources are available for subsurface simulations, ranging from molecular-level to field-scale modeling of multiple tank waste plumes within tank farms. EMSL also has a Subsurface Flow and Transport Experimental Laboratory for porous media physical characterization and automated flow cells of different scales for reactive transport experiments in saturated and unsaturated porous media. A dual-energy gamma radiation system enables water and airfilled pore space to be accurately determined, while a fully automated, state-of-the-art saturation-pressure apparatus measures hydraulic conductivity at different water contents.

During Phase 2 of the TFVZP, PNNL will continue to access other DOE SC investigators and facilities at different locations to study various scientific aspects of contaminated tank-farm sediments. The DOE SC synchrotron facilities (Stanford Synchrotron Radiation Laboratory, the Advanced Photon Source at Argonne National Laboratory, and the Advanced Light Source at Lawrence Berkeley National Laboratory) were extensively used during Phase 1 for X-ray spectroscopy chemical speciation measurements and X-ray chemical distribution imaging to provide important insights on contaminant molecular speciation and physicochemical associations. The wrap-around science program successfully transported and analyzed some of the most radioactive samples studied to date at these facilities without mishap. The resulting analyses have provided underpinning for more accurate conceptual and numeric reaction models to forecast contaminant migration in the tank farms and have been extensively published.

Another facility available for Phase 2 is the Center for Isotope Geochemistry at Lawrence Berkeley National Laboratory (LBNL), where basic and applied geochemical research has been performed using the isotope ratios of:

- light elements, including hydrogen, carbon, nitrogen, oxygen, and chlorine

- strontium

- uranium. 
The facilities include various mass spectrometer and preparation systems to enable some of the most sensitive isotopic signature measurements available world-wide. Isotopic measurements of different elements have provided insights on rates of vadose zone recharge, natural groundwater sources beneath the Hanford reservation, and origins of nitrate and uranium in Hanford groundwater plumes. 


\subsection{Source Term Identification and Contaminant Release}

The tank waste source term is of critical importance (Mann et al. 2007) to tank-farm corrective actions, mitigation, and closure. Capabilities are critically needed to unequivocally identify tank-farm contributions to existing groundwater contamination to guide effective corrective actions, and to understand and predict how residual tank waste left in ground after closure may function as a contaminant source term to the underlying vadose zone.

\subsection{Source-Term Identification}

Objective: Understanding the waste source of contaminants in the vadose zone or groundwater is a critical prerequisite in devising effective corrective actions and mitigation strategies, as source-term control is typically the first step applied. Accurately identifying waste sources associated with the tank farms, however, is complicated by the presence of cribs and trenches associated with tank farms that received dilute tank waste or waste streams of different types. Isotopic methods based on sophisticated mass spectrometry measurements have been developed and successfully applied selectively in the tank farms during Phase I for source differentiation, as the isotopic composition of waste is a sensitive consequence of fuel source and reactor conditions.

Approach: Additional research is required in Phase 2 to:

- establish more sensitive isotopic analytical methods for diagnostic elements

- develop isotopic databases for critical tank-farm waste sources

- understand subsurface transport processes that may modify isotopic signatures or migration velocities in ways that influence the usefulness of isotopic signatures in waste source tracking.

In particular, activities in the following areas need to be pursued:

- Uranium isotopes present in Hanford waste streams have a wide range of isotopic ratios and consequent distinctive signatures due to isotopic enrichment and transformations during the operation of nuclear reactors. Natural background $\mathrm{U}$ also displays an isotopic signature that contrasts with waste $U$ as a result of natural source and alpha-recoil effects. High-precision isotopic measurements can therefore resolve natural from waste $U$ and identify potential fuel sources from which contaminant $U$ has originated. These methods will be applied to varied contaminated waters from vadose zone and groundwater plumes in the tank farms to delineate the contributions of complex waste sources and elucidate the history of contamination.

- Analytical methods will be further developed for isotopic quantification of mobile oxyanion fission products, including $\mathrm{Ru}, \mathrm{Se}$, and Mo, as an improved diagnostic for the presence of tank waste in groundwater. Research will:

- delineate isotopic variability in contaminated subsurface samples of known waste origin using multiple fission product elements/isotopes

- relate the isotopic signatures to source variations

- use the isotopic distributions to develop methods for elucidating redox and ionic charge speciation of mobile fission products in the subsurface. 
The spatial distribution and speciation of fission product signatures will provide data constraints to model reactive transport processes in the tank farms and an additional analytical tool to quantitatively assess specific tank contributions to groundwater contamination.

- The $\mathrm{N}$ and $\mathrm{O}$ isotopic signature of nitrate is different in tank waste, low-activity liquid waste, and Hanford natural waters (soil, vadose zone, groundwater, and river). These differences provide a signature for nitrate source identification where concentrations alone would not be a distinguishing factor. This technique is particularly valuable as nitrate is a conservative tracer of water movement, and its isotopic composition can be used to identify the presence of tank waste before the arrival of retarded contaminants. Additional analyses of vadose zone and saturated zone water samples will refine the understanding of nitrate isotopic variability originating from varied Hanford waste streams. This will improve source identification and risk assessment of mobile contaminants and the design/permitting of corrective measures where appropriate.

Benefit: Improved analytical methods for various mobile multi-isotope elements; a rigorous database; and understanding of the fundamental variations in isotopic signature with waste stream, fuel source, and other operational variables will provide quantitative means to assess tank-farm impacts to groundwater, including dilution factors and mixing fractions. The analyses will provide more definitive conceptual models of tank-farm source terms, contaminant fluxes, and transport as needed in the design of costeffective corrective measures.

Schedule: This proposed area of research includes a methods development phase from 2009 to 2011 and an application phase from 2011 to 2019.

\subsection{Tank Chemistry Evolution}

Objective: A critical need for tank-farm closure is credible prediction of contaminant release concentrations from different residual waste types as a function of time, stabilization materials, and moisture flux. A key aspect in such prediction is to develop scientific understanding of post-closure tankchemistry evolution because contaminant release rates are controlled by the integrated effects of tank chemistry and diffusive or advective moisture flux. Knowledge regarding the distribution of contaminants between different crystalline and amorphous waste mineral forms at the time of closure; and the identity, effects, and rates of abiotic and microbiologic transformation reactions that modify contaminant distribution and major ion concentrations (e.g., $\mathrm{Fe}, \mathrm{Al}, \mathrm{H}^{+}$, and $\mathrm{CO}_{3}$ ) after closure are important needs.

Approach: Experimental research will develop this information using a suite of residual wastes that vary in process origin as well as chemical and mineralogic character, and they represent those likely to be left in-ground. Innovative experimental designs will be established to simulate long-term phenomena.

- Characterization methods previously applied to residual tank wastes will be augmented with more sensitive microscopic and spectroscopic techniques to identify host mineral phases controlling contaminant release and their compositional, morphologic, structural, surface chemical, and solubility properties. These techniques will include transmission electron microscopy, Mossbauer spectroscopy, and micro X-ray diffraction among others. Additional measurements using X-ray based, synchrotron spectroscopies will define the bonding environments of varied contaminants in residual waste as a basis for predicting long-term solubility trends. 
- Laboratory studies will investigate sequestration mechanisms and abiotic release rates of risk-driving contaminants from dominant waste host phases [present in either sludge or salt-cake waste; presumed to be $\mathrm{Fe}(\mathrm{III})$ and $\mathrm{Al}(\mathrm{IV})$ oxides] under expected post-closure chemical regimes. Experiments will be performed with tank waste mineral separates and with synthetic host phases that are precipitated under controlled conditions over ranges of simulated tank-waste $\mathrm{pH}$ and contaminant concentrations. A combination of advanced characterization measurements and kinetic dissolution experiments of different types will be performed on the mineral residues to provide a fundamental database to develop scientifically sound kinetic release models.

- Experimental studies will evaluate chemical compositional changes and their attendant effects on mineral stability, distribution, and contaminant solubility that may occur to tank waste as a result of stabilization by grout or other materials and recarbonization. The experimental approach will be dictated by the physical nature of stabilized residual waste, but initial studies will focus on the kinetic release of major-ions and contaminants from crushed samples that are contacted with electrolytes of different, but representative, compositions at different temperatures. Research will identify reaction networks that control and are associated with tank waste chemical evolution and that are likely to regulate long-term contaminant release.

- Residual tank wastes of varied composition will be inoculated with tank-farm vadose zone sediments, and specific microbial isolates from the SX-108 contaminant plume core to investigate potential long term effects of microbiological activity on contaminant distribution, speciation, and release rates. Specialized laboratory microcosms will be designed to study this complex issue and to monitor biologically driven changes to aqueous and solid associated contaminants and host phases. Microbial activity will be driven by the addition of relevant forms and concentrations of organic carbon and/or electron donors.

Benefit: New analytical and experimental information on the mineralogic residence of key contaminants in various tank wastes, as well as on the identity, rates, and effects of abiotic and microbiologic processes that will cause evolution in tank waste chemistry will provide insights as to whether contaminant sequestration will increase or decrease over long in-ground residence times.

Schedule: The schedule for this proposed area of research will be from 2009 to 2016.

\subsection{Source Term Release}

Objective: Predictions of potential contaminant releases from in-ground residual tank waste after closure will be made by computer models that:

- integrate a large amount experimental data and parameters (thermodynamic, kinetic, etc.) with numerical descriptions of controlling processes, including geochemistry and hydrology

- extrapolate experimental data and process-descriptive relationships to varied conditions as defined by scenario.

The scientific defensibility of these models will depend on the robustness of the experimental database (e.g., contaminant release over relevant time frames, water flux rates, and evolving chemical conditions) and process-descriptive relationships controlling release as well as the quality of process-descriptive parameters. 
Approach: Research is required to develop a robust, comprehensive, and standardized database on contaminant release from residual waste; and generalized, process-based models derived from these data that accurately describe release behavior over both measured and extrapolated conditions.

- An experimental kinetic database on contaminant release from residual tank waste will be developed that that will serve as basis for integrated model development, calibration, and confirmation. Experimental systems will include batch waste suspensions and diffusion cell and column experiments with diffusive and/or advective water transport. Standardized experimental conditions (e.g., water advection rates, temperature, influent electrolyte concentrations and $\mathrm{pH}$, stop-flow durations) will be identified (based on Phase 1 research and new studies) that provide the most accurate and robust representation of the post-closure waste environment and/or that effectively simulate the long-term weathering process. These approaches and conditions will be applied to quantify the contaminant release process from representative tank residual wastes of different type and composition and to identify chemical reactions and mineralogic properties controlling it. The use of standardized conditions will maximize the comparability of results from different waste types and allow rigorous interpretation of contaminant and bulk ion leaching rates.

- A robust, scientifically credible simulator will be developed to forecast post-closure contaminant release rates from residual tank waste. Geochemical transport models that include kinetic reactions, multiple reaction paths, high ionic strength, and diffusive and advective water transport will be modified as needed, parameterized, and applied to simulate tank waste chemical evolution and contaminant solubilization. Candidate models will be carefully evaluated for their capability to describe processes (chemical and transport) shown to control chemical evolution and contaminant release from residual tank waste in varied experimental systems. The best code will be parameterized using the standardized database described above, updated with the most current and robust thermodynamic database for tank waste constituents, and used to evaluate various post-closure scenarios. Selected new experimentation will be performed outside of the parameter space of the kinetic database and/or using different waste materials to evaluate the capability of the model to extrapolate to different conditions.

Benefit: Tank-farm closure decisions will strongly rely on computer simulations of potential contaminant fluxes from in-ground tank wastes for various and multiple environmental scenarios. The defensibility of these calculations will be improved if they are based on experimental data collected over a meaningful and relevant range of conditions and if cause-and-effect relationships are handled through transparent process-based models that incorporate scientific and system reality. The resulting mechanistic sourceterm models will be more scientifically defensible and less conservative, which may reduce the costs of tank-farm closure.

Schedule: The schedule for this proposed area of research will be from 2011 to 2018. Source-term release calculations will rely on other research areas that need to be completed first. 


\subsection{Recharge and Moisture Flow}

This section discusses recharge, including during operations before barrier emplacement, recharge through barriers, and evaluation of post-closure conditions. Moisture flow is also discussed, including geophysical approaches for 3-D geofacies characterization, heterogeneities and lateral flow, and moisture flow under dry conditions.

\subsection{Recharge}

Infiltration and natural recharge provide the driving force for unsaturated water and vapor movement and control the conditions under which contaminants will release and migrate through the vadose zone. The estimates of recharge in tank-farm assessments have been controversial because of many uncertainties, including the effects of gravel cover, devegetation, and lateral flow. Consequently, regulators have forced the use of assumed rates that lead to biases and uncertainties in resulting assessments. The long-term performance of barriers has been studied at the prototype barrier site constructed over the 216-B-57 crib (immediately north of the BY tank farm). This site continues to offer research opportunities in support of barrier design and performance for the tank farms.

\subsubsection{Operational Recharge Before Barrier Emplacement}

Objective: Research is needed to develop an accurate estimate of Hanford recharge at specific tank-farm locations such as C Farm. These estimates are needed for undisturbed and operational conditions.

\section{Approach:}

- Recharge for undisturbed conditions will be estimated with isotopic tracers. In most applications, only a single tracer is used, which means that uncertainties cannot be constrained. Research will investigate the use of a multi-tracer methodology that includes ${ }^{2} \mathrm{D} /{ }^{18} \mathrm{O}, \mathrm{Cl},{ }^{36} \mathrm{Cl}, \mathrm{I}, \mathrm{U}, \mathrm{Sr}, \mathrm{Br}, \mathrm{SO}_{4}$, and chlorofluorocarbons. Each of these has been used in some fashion to estimate recharge, but almost never together. This study will focus on a natural setting to minimize any impacts from Hanford operations. We will analyze a comprehensive suite of tracers in several sets of continuous, undisturbed cores from the 200-East Area and the 200-West Area to develop a complete and statistically sound record of pre-Hanford recharge (1000s of years ago to present). This record can be used as a benchmark for nearby single-tracer studies associated with individual tank farms. Furthermore, this research will help to resolve the outstanding issue of anthropogenic chloride deposition, and it will provide an independent verification of the $\mathrm{Sr} / \mathrm{U}$ recharge estimation method developed using cores from the SX tank farm.

- Recharge for operational conditions will be determined by direct measurement and by soil physics model calculations that include thermal and air phases and the impacts of gravel covers with varying concentrations and layering of fines. Direct measurements of recharge in tank farms are a critical need, yet achieving the goal has remained elusive for a variety of technical and operational reasons. Research will be conducted to design and build a device that can be deployed to multiple locations within individual tank farms to measure recharge. The device must be robust and reliable, as demonstrated with performance data under real conditions. Recharge estimates may also be derived from seasonal measurements of moisture profiles in vadose zone monitoring wells with neutron probes. Calibration, however, that is required for each individual borehole is costly and time 
consuming, not reproducible, and not transferable to replacement probes. Research will be conducted to develop a generalized and transferable neutron-probe calibration methodology using a code such as Monte Carlo Neutron-Photon (MCNP).

Benefit: Improved and validated estimates of recharge obtained by multiple methods for individual tank farms will negate the need to use one assumed, less accurate value. The improved recharge estimates will enable tank-farm-specific assessments of barrier performance and reduce uncertainties in predictions of recharge-driven contaminant migration.

Schedule: The schedule for this proposed area of research will be from 2009 to 2014. Recharge is information that is needed by other research areas and for performance assessments.

\subsubsection{Recharge Through Barriers}

Objective: Surface barriers to reduce infiltration and recharge that drive contaminant release and migration are a primary corrective and remedial-action approach planned for the tank farms. The depth to which surface barriers impact recharge is an important area of uncertainty. Effective barrier design requires approaches to estimate the depth of barrier effectiveness given area and configuration of surface coverage, subsurface conditions, and performance metrics, such as impact on recharge.

Approach: A combination of field measurements and modeling is needed to verify that tank-farm barrier designs perform as desired over the design life.

- The current monitoring system beneath the prototype barrier and the T Tank Farm interim barrier cannot be used to identify the depth to which the surface barrier is effective. This is problematic to the design of effective long-term barriers for tank-farm closure. Consequently, geophysical approaches to monitor water content beneath Hanford barriers will be evaluated in research that targets multiple locations exhibiting covered and uncovered conditions as well as different hydrogeologic properties. The prototype barrier will be investigated because of its historical record and ease of instrument access to directly observe how barrier construction has influenced the depth and spatial distribution of vadose zone moisture contents. A variety of geophysical techniques, including cross-borehole radar, will be used to monitor water content and distribution.

- The vadose zone hydrologic model has been upgraded and parameterized to realistically model unsaturated permeability anisotropy caused by fine-textured silt lenses. Water flow at low moisture content will be used in sensitivity analyses to comprehensively evaluate issues of barrier depth effectiveness for various scenarios of barrier configuration and runoff, initial conditions including hypothesized waste distribution or plume configuration, subsurface conditions, barrier recharge rates, and future climatic changes.

Benefit: This research will provide the scientific basis for barrier design that will verify desired environmental protection and function as well as cost effectiveness. The results will reduce uncertainties in the extent of recharge-driven contaminant migration.

Schedule: The schedule for this proposed area of research will be from 2009 to 2014. Recharge data and effective models will be needed early during Phase 2 to influence surface barrier design and as input to performance assessments. 


\subsubsection{Evaluation of Post-Closure Recharge}

Objective: A key issue of concern for stakeholders is the uncertainty in recharge conditions that will exist long after tank farms are closed. Specifically, the concerns center on future precipitation, temperature, wind, soil, and vegetation conditions and how those conditions differ from the present.

Approach: A framework for identifying and evaluating future recharge scenarios will be established. The scenarios will be linked to predictions of regional weather due to predicted global climate changes. Functions will be developed to translate weather impacts into changes in soil and vegetation conditions, which in turn will be translated into changes in recharge. The initial evaluation will focus on the potential for sand dune migration and formation above a tank farm during a warmer and drier climate. The evaluation will address potential source areas and volumes, land use, and location relative to the prevailing winds.

Benefit: Residual tank waste and derived residuals will exist in the Hanford subsurface for the foreseeable future. The last 50 years have seen considerable change in climate that is expected to accelerate in the future. This research will provide the scientific basis for assessing the impacts of climate change on longterm recharge through surface barriers. These results will help verify a desired environmental protection and surface barrier function that is cost effective.

Schedule: The schedule for this proposed area of research will be from 2009 to 2014. Post-closure recharge data will be needed early during Phase 2 as input to performance assessments.

\subsection{Moisture Flow}

Water entering the vadose zone through meteoric recharge and/or waste or retrieval water discharge is subject to complex forces associated with unsaturated moisture flow. Credible performance assessments of waste-form stability, contaminant release from residual tank waste, and migration of tank waste residuals from past releases rely on the ability to forecast the direction and velocity of water migration and associated changes to water content. These capabilities, in turn, require a firm and rigorous understanding of water movement in the Hanford vadose zone and the properties that control it as well as models that appropriately embody this understanding. The fact that contaminants are reaching groundwater more rapidly than expected is evidence that the required understanding of vadose zone moisture flow has not yet been achieved. Research will resolve key remaining uncertainties.

\subsubsection{Geophysical Approaches for 3-D Geofacies Characterization}

Objective: The spectral gamma logging system (SGLS) is performed in boreholes placed near or within the tank farms, near tanks being retrieved to detect losses, and in areas where vadose zone radionuclide contamination exits. SGLS is the method of choice to monitor contaminant release and migration in the tank farms, and a large evolving SGLS database exists as new boreholes are logged and older ones relogged. In addition to monitoring anthropogenic radionuclides (e.g. ${ }^{60} \mathrm{Co}$ and ${ }^{137} \mathrm{Cs}$ ), SGLS provides a wealth of detailed, vertically resolved data on natural isotopes $\left({ }^{40} \mathrm{~K},{ }^{238} \mathrm{U}\right.$, and $\left.{ }^{232} \mathrm{Th}\right)$, known to be correlated at other sites with geologic facies, and properties controlling moisture retention and flow. This information has not been previously used at Hanford. 
Approach: Research will develop Hanford-specific correlations between these natural isotopes and subsurface geohydrologic properties for more accurate and resolved subsurface properties discrimination in the tank farms and their proximate environs. Uncontaminated subsurface sediments $(\sim 50)$ from tankfarm-associated boreholes (e.g., from placement of RCRA wells) that vary in depth, collection location, color implying mineralogic or lithologic differences, and texture will be selected for study. These will be fractionated by size (e.g., gravel, sand, silt, and clay) and each fraction analyzed for ${ }^{40} \mathrm{~K},{ }^{238} \mathrm{U}$, and ${ }^{232} \mathrm{Th}$ with high-precision counting methods. The semi-quantitative mineralogy of each fraction will be determined by powder diffraction and the chemical composition of key bulk analytes determined by Xray fluorescence. Correlations of various types will be drawn between grain size, isotopic concentrations, and other measured properties to establish litho-facies predictive relationships from SGLS logs of the natural isotopes. Physically based, interpretation tools will be developed for predicting hydraulic and transport properties from these easily measured high-resolution borehole geophysical logs.

Benefit: Thin silt and sand layers have been shown to have a large effect on water and contaminant migration in the vadose zone. They often cause significant lateral spreading of tank waste solutions and increase physical retardation. This research will develop necessary relationships to identify these features from commonly collected geophysical data, dramatically improving the resolution of geofacies characterization in the tank farms and the quantitative ability to model moisture content and migration, leading to the development of effective tank-farm closure strategies.

Schedule: The schedule for this proposed area of research will be from 2009 to 2014. Approaches for predicting the impact of fine-scale layering on moisture flow and contaminant transport are needed early in Phase 2 to support remediation design and as input to performance assessments.

\subsubsection{Heterogeneities and Lateral Flow}

Objective: Field data and modeling performed for tank-farm assessments demonstrate that the natural heterogeneity of Hanford sediments plays an important role in lateral flow and transport. Considerable progress has been made and theories developed for incorporating these phenomena into hydrology models, but the need exists for further testing and development of appropriate approaches for quantifying heterogeneities and moisture-dependent anisotropy to develop robust 3-D models of the vadose zone.

Approach: Laboratory investigations will be used to quantify hydraulic properties and their spatial variation for detailed modeling of the vadose zone, including representing the effects of heterogeneities and anisotropy on moisture flow and contaminant transport. The important processes governing unsaturated water movement under pre- and post-closure (i.e., at low moisture) conditions will be characterized. Characterization data will be collected to improve the understanding of the lateral continuity of geologic units in the vadose zone to further quantify processes governing unsaturated water movement and generate site-specific relationships that can be directly applied to closure decisions. Field data collection will rely on surface geophysics and cross-borehole measurements. Outcrop and excavation data as well as closely spaced push boreholes can be used for calibrating geophysical measurements. The studies will determine if fine-grained units have a different horizontal continuity than coarse-grained units, which might have a significant impact on the relative rates of lateral versus vertical flow and transport.

Benefit: This research will provide data and detailed models of lateral flow and transport. These results will be used to improve the design of tank-farm remediation and closure actions. The extent of lateral 
continuity of geologic units and the lateral flow of contaminants that might be associated with it is unclear. Lateral spreading generally reduces the potential for vertical migration to groundwater. However, lateral transport could, in some circumstances, focus the movement of contaminants into regions of higher recharge and/or higher moisture content, or into contact with a vertical discontinuity (e.g., a poorly-cemented borehole), thus enhancing vertical contaminant movement.

Schedule: The schedule for this proposed area of research will be from 2009 to 2014. Approaches for predicting the impact of heterogeneities on moisture flow and contaminant transport are needed early in Phase 2 to support remediation design and as input to performance assessments.

\subsubsection{Moisture Flow Under Dry Conditions}

Objective: Engineered barriers are expected to reduce recharge rates in closed tank farms by an order of magnitude or more. The objective of such recharge reductions is to reduce the hydrologic driving force for migration of vadose zone contaminants resulting from past releases and to minimize the amount of water available to interact with stabilized, residual tank waste. The magnitudes of water fluxes beneath such barriers are projected to be close to the uncertainties inherent in measuring or calculating these values with current technologies or models. Improved, confirmed modeling capabilities are consequently required to describe moisture flow under recharge and hydrogeologic conditions anticipated to exist beneath tank-farm closure barriers.

Approach: Laboratory experiments will be used to develop a new relationship between unsaturated hydraulic conductivity and water content at low moisture contents or to validate existing literature relationships. The importance of vapor flow and transport at low moisture content and soil matric potential will also be evaluated and incorporated in constitutive models that will be tested against laboratory data generated with tank-farm vadose zone sediments and field data collected from barrier study sites. Laboratory studies will also be performed to quantify osmotic effects (e.g., water movement toward salt) on water and solute distributions near saline/sodic waste plumes in the tank farms. Such plumes are expected to be capped as part of closure activities, but may function as long-term moisture sinks for lateral flow, with potential wetting occurring over the long term. Results will be integrated into PNNL's water flow models that properly account for anisotropic moisture flow in the vadose zone.

Benefit: Research will resolve basic issues such as direction and rate of water movement and controls on unsaturated fluid flow in tank farms where surface barriers may be installed and where high-salt plumes exist. Models and associated parameters will be established for credible calculations of moisture flow under the dry conditions that will be imposed after tank-farm closure. These relationships will be used in detailed models of post-closure conditions within tank farms to improve the design of tank-farm remediation and closure actions.

Schedule: The schedule for this proposed area of research will be from 2012 to 2016. Approaches for modeling moisture flow and contaminant transport under dry conditions will be incorporated into integrated models later in Phase 2. 


\subsection{Contaminant Mobility}

This section discusses key COC for tank-farm closure, including uranium and anions, and in situ measurements of migration velocities and flux. Also discussed are coupled reactions and mass transfer and slow reactions, microbiologic transformations and reactions, and multi-process data integration.

\subsection{Key Contaminants of Concern for Tank-Farm Closure}

Remedial actions required for the tank farms are based on projected contaminant concentrations in groundwater at tank-farm boundaries and the Columbia River. These projections are based on in-ground inventory and inventory depth and assumptions regarding the magnitude of retardation typically described by $\mathrm{K}_{\mathrm{d}}$. Risk is assigned to a given contaminant based on the extent to which its projected groundwater concentration exceeds the drinking water standard or the maximum concentration level (MCL). High risk contaminants, or COC, are consequently those that through a combination of inventory and retardation yield high groundwater concentrations. Remedial actions are performed specifically to reduce risk or lower the projected concentrations of COC in groundwater. The SST-PA(DOE ORP 2005) has identified

${ }^{99} \mathrm{Tc}, \mathrm{Cr},{ }^{129} \mathrm{I}$, and $\mathrm{U}$ as tank-farm COC based on these criteria. Obviously, there are other contaminants in tank waste that are also of environmental concern, and others may become $\mathrm{COC}$ as new information becomes available.

The need to predict contaminant concentrations in groundwater that result from tank-farm operations as a basis for risk assessment and the application of remedial actions as a means of risk reduction mandates that a firm and fundamental understanding be in hand of vadose zone contaminant transport processes. An inadequate understanding might lead to erroneous risk assessment and/or the application of excessive and overly costly remediation actions.

\subsubsection{Uranium}

Objective: Uranium (U) is an important contaminant in tank farms where first cycle bismuth-phosphate waste (or metal waste) was accidentally released to the vadose zone. Uranium is moderately reactive with Hanford subsurface sediments, depending on waste chemistry and sediment mineralogy and texture, but its geochemical behavior is not sufficiently understood to allow defensible predictions of $U$ migration velocity.

Approach:

- Research will be performed to establish predictive relationships between subsurface and waste properties and the identity, rate, and extent of $U$ adsorption and precipitation reactions that control solid-liquid distribution and porewater $\mathrm{U}$ concentrations.

- A generalized model will be developed based on new experimental measurements that can predict the solid-liquid distribution of U(VI) and its reactive transport behavior under the variety of waste, geochemical, and hydrologic conditions present in tank-farm vadose zones. This activity has been underway for approximately 3 years with significant progress made through studies of contaminated sediments from the BX-102 and TX-104 boreholes. Additional studies will investigate:

- how dissolved U(VI) is retarded by deep vadose zone sediments over the range in physical, chemical, and mineralogic properties found beneath current in-ground plumes 
0 reaction competition and dominance for chemically concentrated systems where reaction networks evolve in a down-gradient direction from precipitation/dissolution to those dominated by adsorption/desorption.

A parameterized, multi-component model will result that accounts for the effects of U(VI) concentration, $\mathrm{pH}$, carbonate concentration, and sediment properties on U(VI) retardation.

Benefit: A well-formulated experimental program will yield a generalized model and reaction parameters to predict aqueous concentrations and the migration velocity of contaminant U(VI) in different waste streams and Hanford tank-farm sediments of diverse properties. Understanding and predicting contaminant mobility will directly impact tank-farm remediation design and closure actions.

Schedule: The schedule for this proposed area of research will be from 2009 to 2011. Research on this topic has been underway and can be completed with a concerted effort early in Phase 2.

\subsubsection{Anions}

Objective: Anionic chemical and fission product contaminants are the most mobile tank waste contaminants in the vadose zone and are major risk drivers. They form weak adsorption complexes on Hanford sediments and are poorly retarded in consequence. Technetium $\left({ }^{99} \mathrm{Tc}\right.$, as $\left.\mathrm{TcO}_{4}{ }^{-}\right)$and chromium $\left(\mathrm{Cr}\right.$, as $\left.\mathrm{CrO}_{4}{ }^{2-}\right)$ are anionic tank waste $\mathrm{COC}$ that are major risk-driving contaminants. Ratios of different tank waste anions are often used to infer origins and degree of tank waste contribution to groundwater contamination beneath the tank farms. However, characterization measurements of tank waste plumes have shown different chromatographic profiles for these mobile anions, indicating variable degrees of retardation whose mechanisms and extent are not understood or quantified.

Approach: Research will focus on the fate of fission product and process anions that are:

- the most mobile of tank waste constituents

- risk-driving COC

- indicative of specific waste sources, including ${ }^{99} \mathrm{Tc},{ }^{129} \mathrm{I}, \mathrm{Cr}$, various isotopes $\mathrm{Ru}$, various isotopes $\mathrm{Mo},{ }^{79} \mathrm{Se}$, and possibly ${ }^{60} \mathrm{Co}$-cyanide (if interest exists given the short half-life).

Laboratory interaction studies will develop a generalized model of anion reactivity that quantitatively describes field chromatographic and contaminant valence profiles measured in tank waste plumes. Experiments using relevant vadose zone sediments of different but representative properties from various tank farms will define the extent and rate of adsorption, reduction, and oxidation reactions that may potentially retard or sequester otherwise mobile oxyanions. Initial research emphasis will be on the role of native iron-containing minerals (oxides and phyllosilicates) and ferrous iron released by tank wasteinduced dissolution reactions of chlorites and other relatively soluble mineral phases.

Benefit: Quantitative information will be developed on anion mobility for enhanced interpretation of waste plume migration velocities, improved predictions of future "fence-line" groundwater concentrations, and overall risk protection and reduction. Insights will be provided on the reliability of using these constituents for waste source tracking and the types of remedial approaches that may be effective. 
Schedule: The schedule for this proposed area of research will be from 2010 to 2015 . Research on this topic is staggered with $\mathrm{U}$ mobility research.

\subsection{In Situ Measurements of Migration Velocities and Flux}

Objective: Characterization studies of vadose zone tank waste plumes have been static ones based on sediments collected at a single time point (e.g., a borehole or direct-push sediment collection). While these provided invaluable information on contaminant chromatography, depth distribution, and associated physical, chemical, and geologic properties, little information exists on the current migration velocity and fluxes of key tank waste constituents (e.g., ${ }^{99} \mathrm{Tc}_{\mathrm{c}}$ and $\mathrm{NO}_{3}{ }^{-}$) in the deep vadose zone. It is thus unclear whether tank waste plumes represent:

- historic transport events that occurred rapidly after tank waste release or

- features that evolved through drainage, meteoric recharge, and slow migration.

Direct or credible inferred measurements of migration velocity in the deep vadose zone are critically needed to provide model-independent parameters and to validate calculations.

Approach: High-density geophysical data sets will be obtained for key tank waste plumes over appropriate time or delay intervals that have documented release histories and that display the potential to yield information on migration velocity. The data will be obtained through mining of historical measurements or new and systematic repeat logging (by SGLS or other chemically/radiologically sensitive tools). The resulting data on changing contaminant depth distributions with time will be interpreted by traditional moment analyses and reactive transport modeling (using the best geologic, hydrophysical, and geochemical information) to yield migration velocities (in $\mathrm{m} / \mathrm{d}$ or equivalent). Other new-generation down-hole measurement approaches being developed by the geophysical research community that might become available during the period of tank-farm closure will also be sought and evaluated to obtain this critical information.

Benefit: Direct measurements of migration velocity in the deep vadose zone will allow improved modeling of contaminant arrival times and concentrations at regulatory boundaries. Such measurements would also allow better design of remediation and monitoring systems.

Schedule: The schedule for this proposed area of research will be from 2010 to 2013. Measurements of migration velocity are needed to support modeling that will be developed later in Phase 2.

\subsection{Coupled Reactions}

Objective: Ion exchange and precipitation/dissolution reactions control porewater composition and intragrain contaminant sequestration in deep unsaturated vadose zone sediments that have been impacted by tank waste. The qualitative effects of these reactions on porewater constituents have been observed in Phase 1 characterization studies, and certain patterns are considered diagnostic of tank waste contact and the depth location of the waste front. However, these reactions have not been sufficiently quantified and parameterized to allow the locations of ion exchange and precipitation fronts to be predicted relative to the mobile anion front (e.g., Tc and $\mathrm{NO}_{3}$ ) in the field as required for reactive transport analysis. 
Approach: Laboratory investigations using deep vadose zone sediments (contaminated and uncontaminated) will identify and parameterize the processes controlling porewater composition under unsaturated conditions to the point of being able to predict them for important sediment-tank waste scenarios. Experimentation will emphasize water-unsaturated reactive transport processes using tankfarm sediment columns with moisture potentials controlled by vacuum chambers. Coupled hydrologicgeochemical processes will be characterized that occur in tank waste-impacted, deep vadose sediments at relevant moisture contents and fluxes, and contact times. Key reactive transport properties will be measured (e.g., cation exchange capacity, surface area, or other) on tank-farm sediments from different spatial locations and depths as needed to incorporate important geochemical heterogeneities into reactive transport simulations of different waste release events and future migration. Methods will be developed to predict evolving porewater composition in sediments of different types as required to:

- describe the geochemical reactions of contaminants retarded by precipitation/dissolution or adsorption/desorption such as U

- interpret chromatographic profiles of vadose zone tank waste plumes.

Benefit: Models will be developed that can be used to predict evolving porewater composition in sediments of different types required to describe geochemical reactions and interpret chromatographic profiles of vadose zone tank waste plumes. These data, insights, and models will facilitate decisions regarding whether deep vadose zone plumes can and should be remediated or left in place, a key aspect of tank-farm closure.

Schedule: The schedule for this proposed area of research will be from 2012 to 2015 . Coupled reactions are staged to rely on input or other process-level models.

\subsection{Mass Transfer and Slow Reactions}

Objective: Most discharges of tank waste to the vadose zone occurred many years ago (e.g., 1950-1970) during periods of active fuel rod reprocessing, intense radioactive decay of short-lived fission products, fission product extraction (e.g., ${ }^{90} \mathrm{Sr}$ and ${ }^{137} \mathrm{Cs}$ ), $\mathrm{U}$ recovery, and movement of wastes between tanks to optimize storage. Consequently, tank waste residuals have remained in the vadose zone for extended periods, allowing slow sediment-waste geochemical reactions and solute diffusion into poorly accessible micropores and microfractures in sediment lithic fragments. Increasing evidence indicates that a sizable inventory of tank waste residuals reside in these microscopic physical domains that can exhibit unique reactivity. Such micro-pore residence can sequester otherwise mobile contaminants and delay solute release to porewater for mitigation, remediation, or transport.

Approach: Research will determine the role of mass transfer in limiting the release of sorbed tank waste residuals of different form and reactivity from contaminated tank-farm sediments. Waste composition and temperature were major factors controlling the extent of sediment dissolution and precipitation that occurred after waste discharge, and these are speculated to control the magnitude of the labile (or migrating) contaminant fraction. Sediments will be obtained from Phase 2 tank-farm characterization studies. New research will identify the rates of contaminant exchange between sediment particles and unsaturated porewaters as well as particle physicochemical properties (e.g., porosity, pore size, and tortuosity) controlling non-reactive and reactive mass transfer. A grain-scale model will be developed to describe these mass-transfer kinetic effects that can be linked with a reaction-based reactive transport 
simulator for tank waste vadose zone plumes of varied waste composition and host sediment facies of different properties.

Benefit: Mass transfer and slow reactions will increase the retardation of many contaminants and smear their arrival times at groundwater. Natural reductions in risk will consequently occur. This research will identify the COC and waste matrices for which these processes are operative and develop models to accurately simulate their effect on vadose zone contaminant transport. Mass transfer and slow reactions may influence the long-term behavior of tank farms that are closed.

Schedule: The schedule for this proposed area of research will be from 2013 to 2017. Approaches for predicting the impact of mass transfer and slow reactions depends on other process-level understanding and can be incorporated later in Phase 2 .

\subsection{Microbiologic Transformations and Reactions}

Objective: Microorganisms exist naturally in Hanford's vadose zone, and others have been introduced and transported to depth following surface soil disturbance and artificial recharge in the tank farms. Microorganisms mediate solute biogeochemical transformations, including oxidation-reduction of polyvalent oxyanions that are common tank waste constituents [e.g., $\mathrm{NO}_{3}, \mathrm{NO}_{2}, \mathrm{U}(\mathrm{VI}), \mathrm{Tc}(\mathrm{VII})$, and $\mathrm{Cr}(\mathrm{VI})]$. Microorganisms influence the properties of reactive minerals via oxidation/reduction or dissolution reactions. Viable and functional radiation- and dessication-resistant microorganisms were observed in highly radioactive sediments from the SX-108 vadose zone plume. Consequently, it is probable that microorganisms will play an important role in influencing the speciation, stability, and migration behavior of vadose zone tank waste contaminant waste before and after closure.

Approach: New research will build upon past studies performed in the SX tank farm to identify prominent organism types present in tank waste plumes of different chemical character and radiation/thermal history to identify their current in situ activities, and to assess their future potential to influence the mobility of key tank waste contaminants [including $\mathrm{Tc}(\mathrm{VII}), \mathrm{Cr}(\mathrm{VI})$, and U(VI)]. Laboratory microcosm experiments will investigate the behavior of the in situ community under moisture and nutrient fluxes observed in tank waste plumes, and those that may be expected after closure. These studies will evaluate the impact of tank waste nutrient ions (e.g., $\mathrm{NO}_{3}, \mathrm{NO}_{2}$, and $\mathrm{PO}_{4}$ ) on:

- microorganism populations, activity, and functional types

- direct and fortuitous microbiologic solubilization and immobilization reactions of tank waste contaminants.

Unexpected effects may result from biologically induced redox or pore-water composition change, majorion transformations (e.g., dissimilatory $\mathrm{NO}^{3-}$ reduction to $\mathrm{NH}^{4+}$ with subsequent displacement of ion exchangeable ${ }^{137} \mathrm{Cs}^{+}$or ${ }^{90} \mathrm{Sr}^{2+}$ ), production of reactive organic molecules (e.g., complexants), or mineral composition/structure changes.

Benefit: This research will provide needed insights on the unknown influence of subsurface microorganisms on tank-farm contaminant migration and in situ sequestration. Both detrimental and positive effects might occur. External science reviewers of tank-farm closure plans will likely demand 
information on this topic because of the well-known biogeochemical influence of subsurface microorganisms on radionuclide fate and transport in different subsurface environments.

Schedule: The schedule for this proposed area of research will be from 2013 to 2017. Approaches for predicting the impact of microbial transformations and reactions can be incorporated later in Phase 2 .

\subsection{Multi-Process Data Integration}

Objective: Hydrologic, geochemical, and microbiologic processes couple in complex ways to control contaminant migration in the vadose zone. Sometimes the collective effects of these processes on contaminant migration are counter-intuitive because the individual processes exhibit non-linear behavior, and conceptual models of vadose zone contaminant transport may be incorrect. Accurate and scientifically sound future projections of contaminant distributions and concentrations in the tank farms and underlying groundwater therefore require that the collective and interactive effects of these processes be considered within the specific context of tank farms undergoing closure. To enable rigorous performance assessments in the tank farms, new information on vadose zone hydrology, contaminant and major ion (bio)-geochemistry, and mass transfer require formal integration in a multi-dimensional computer simulator that accurately captures the hydrogeology of each tank farm.

\section{Approach:}

- Individual hydrologic and geochemical process models will be improved to be fully consistent with known field conceptual models and laboratory defined behaviors, field characterization data including solute chromatographic separation and moisture content, and other important tank-farm observations, such as borehole geophysics. There will be first-order dependencies of:

- geochemical reaction/retardation on tank-farm sediment mineralogy and $\mathrm{pH}$, reactive surface site concentrations, and waste/porewater composition

- fluid flow on specific facies properties, distributions, and structures at relevant scales will be explicitly included.

Process models of liquid migration and reactive contaminant transport will be tested and confirmed by comparisons to field contaminant and moisture distribution profiles for tank waste plumes that are constrained by knowledge of tank waste release timing, volumes, and compositions.

- An efficient, systems-level simulation framework will be developed to integrate the best information on the variably saturated hydrologic system and reactive transport processes from the various S\&T studies with the goal of reducing the uncertainty in projections of future contaminant transport. These processes include moisture-dependent anisotropy that accounts for the lateral migration of water and contaminants, the effects of low-moisture conditions on unsaturated flow processes and hydraulic properties, and waste-contaminant-sediment interactions of different types. Inverse modeling, constrained by multiple information types (e.g., hydrologic, geochemical, and geophysical) at different space and time scales, will be used to increase the accuracy of facies descriptions in terms of hydrologic and geochemical reaction parameters and essential small-scale heterogeneities. The integrated model will be confirmed by history matching and multi-component contaminant transport calculations for three benchmark tank waste plumes. 
Benefit: Integrative, multi-process models will be used to predict concentrations and locations of tank waste contaminants (e.g., Tc and $\mathrm{NO}_{3}$ ) in areas that are inaccessible and/or where direct characterization measurements do not exist, and to more accurately forecast future migration for various scenarios associated with leaked tank waste, retrieval losses, mitigation activities, and closure for risk assessment and reduction. The resulting model will more accurately forecast future migration for various scenarios associated with tank-farm closure.

Schedule: The schedule for this proposed area of research will be from 2013 to 2017. Multi-process data integration relies on process-level understanding and can be incorporated later in Phase 2. 


\subsection{Tank-Farm Closure Technologies}

Tank-farm closure will be an unprecedented and challenging activity requiring significant technological advances for success. Some technology needs are evident at this time, and others will surface as existing problems are resolved, and the activity proceeds toward completion. Improved technology is needed to characterize the distribution of contaminants resulting from past leaks, to monitor tank leaks during and after retrieval, to stabilize residual waste and prevent infiltration, and to model and monitor tank-farm closure performance.

\subsection{Subsurface Access and Sampling Methods}

Objective: Drilling operations within tank farms require special considerations to deal with extensive subsurface infrastructure as well as contamination and radiation protection. Traditionally, boreholes have been used for access to the subsurface in areas where infrastructure allows. These are created by drilling into the subsurface or pushing a core barrel or open-ended casing to retrieve samples. Borehole drilling campaigns have provided important characterization information for the tank farms, but are very expensive. In areas of high contamination, limitations can be placed on bringing highly radioactive and hazardous waste to the surface. As a remedy, closed-end pipes that are driven or pushed into contaminated sediments have been employed in certain tank farms, but these have been problematic. Significant improvements in sampling methodology and access are generally needed for tank-farm characterization.

Recent developments have focused on a hydraulic hammer that pushed a small diameter casing, at angles, to a depth of 120 feet in the 200-West Area and to 250 feet in the 200-East Area. This technology has benefits, including lower cost, better access in tank farms, recovery of multiple samples, and avoidance of tank-farm infrastructure. However, there are significant limitations that include depth of penetration, small sample size that is inadequate for all but total compositional analysis, and an inability to retrieve highly contaminated samples. Tank-farm closure studies require far more sample than obtained by this method.

Approach: New and/or improved methods for subsurface access and recovery will be identified or developed and tested in the field. Resulting capabilities are needed that retrieve comparable sample volumes to boreholes, but at significantly reduced cost.

Benefit: Workable technologies to improve subsurface access and recovery at a cost below those of boreholes will lead to a more robust tank-farm characterization database on which to base important tankfarm closure decisions.

Schedule: The schedule for this proposed area of research will be from 2009 to 2012 . Methods for subsurface access and sampling are needed early during Phase 2 to support characterization.

\subsection{Field Measurement of COC}

Objective: The measurement of COC subsurface concentrations is vital to tank-farm characterization, remediation, monitoring, and closure. Existing sampling methods are labor intensive and provide data at infrequent intervals, which may be inadequate to understand subsurface changes. The development of 
effective long-term strategies for tank-farm closure and risk reduction management will eventually require automated at-site measurement systems for key COC that provide more frequent temporal analyses of concentration and flux to support:

- site characterization

- evaluations and modeling of contaminant transport

- leak detection during retrieval

- documentation of post-closure performance metrics.

\section{Approach:}

- Development of a ${ }^{99} \mathrm{Tc}$ sensor to be deployed during decommissioning of direct push probe holes. Such a sensor will be based on the robust, existing technology of silicon beta detectors, noting that very few long-lived beta emitting radionuclides exist in the Hanford sediments.

- Automated at-site (tank farm), sensor-based measurement systems that are solar powered and that directly relay results by wireless communication will be developed for key tank farm COC (beginning first with ${ }^{99} \mathrm{Tc}$ ) and associated parameters. The developmental laboratory research will investigate the selectivity, precision, and accuracy of the measurement approaches as they apply to current and evolving tank-farm matrices. The measurement approach will involve either a sensor supported by an automated fluidic system, or more complex multi-step processes involving pre-concentration with secondary analysis. Vadose zone sampling systems will also require development to collect and deliver COC-containing waters from low-moisture-content sediments to the measurement system.

Benefit: This research will provide new in situ measurement capabilities to support robust site characterization and development of sound monitoring systems for tank-farm remediation and closure.

Schedule: The schedule for this proposed area of research will be from 2009 to 2019. Approaches for field measurements of $\mathrm{COC}$ are needed for post-closure monitoring and can be incorporated later in Phase 2.

\subsection{Geophysical Approaches for 3-D Plume Delineation}

Objective: Vadose zone contaminant plumes are inherently 3-D and complex, often reflecting the interplay of surface boundary conditions and subsurface heterogeneity. Contaminant plumes have traditionally been characterized by borehole sampling, which yields an inherent 1-D representation of the multi-solute feature. HRR and SGE are geophysical methods that are beginning to be deployed at the Hanford Site to delineate vadose zone contaminant plumes within and outside of tank farms. These techniques have shown promise for 3-D plume mapping in the tank farms, but an inadequate understanding of the infrastructure effects and geochemical and hydrophysical properties controlling geophysical response prevents sound measurement interpretation.

Approach: Research will be performed to resolve key scientific issues pertaining to the application of HRR/SGE for accurate mapping of subsurface contaminant plumes. Measured field responses using these methods reflect effects of multiple factors, including sediment texture and mineralogy, moisture content, and pore fluid composition. Controlled laboratory studies will be preformed to provide a fundamental 
basis and correlative relationships for quantitative interpretation of HRR/SGE measurement results. Laboratory geophysical measurements will be performed with tank-farm vadose zone sediments spanning a range of representative textures to establish fundamental relationships between hydrologic, transport, and electrical parameters with sediment grain size characteristics as modified by porewater content and composition. The salt content of pore fluids will be evaluated over the range of waste compositions present in the varied tank farms.

Benefit: Establishing fundamental relationships between tank waste compositions, vadose zone hydrophysical properties and moisture content, and electrical parameters measured with geophysics will allow quantitative use of geophysical measurements including HRR and SGE for 3-D tank waste plume mapping. Such capability would allow more accurate and economic surface barrier design to cover spatially complex regions of subsurface contamination and more accurate positioning of any new boreholes for additional characterization.

Schedule: The schedule for this proposed area of research will be from 2009 to 2012. Geophysical characterization of tank-farm vadose zone plumes is underway, and supporting information is needed to quantify the survey results.

\subsection{Leak Detection}

Objective: Vadose zone contamination resulting from historic tank waste releases is a major risk driver for tank-farm closure. Moisture releases during waste retrieval must therefore be minimized to prevent migration of deep vadose zone contaminants and newly solubilized radionuclides and chemical components. Effective and confirmed leak-detection methodologies and strategies are required for tankfarm application before major retrieval campaigns commence.

Approach: The process for gathering environmental and risk-based information in the event of a possible leak during tank waste retrieval is not defined. Because the data associated with movement (transport) of tank wastes lost during a retrieval incident can provide invaluable insight into the long-term movement and associated risks, a plan to capture those data should a retrieval incident take place is essential to verifying that the data are collected in appropriate quantity and quality to conduct the analyses. HRR has been demonstrated for a simulated leak at Tank S-102, and the method is now accepted as a means for tank leak detection. Additional testing and analysis of different measurement systems and configurations, and data interpretational tools are needed to confirm and maximize the effectiveness of prior versions of leak detection systems.

Benefit: An effective leak detection system is required during waste retrieval to verify that additional moisture and contaminants are not released to the vadose zone in the tank farms. Additional moisture and solute releases could expedite the transport of vadose contamination from past releases to groundwater.

Schedule: The schedule for this proposed area of research will be from 2012 to 2015 . Waste retrieval for C Farm is scheduled to start in 2015.

\subsection{Waste-Form Hydrology}

Objective: SSTs that are closed will consist of residual tank waste surrounded by engineered materials, primarily grouts. The hydraulic and geochemical properties of the concrete shell and associated grouts 
and fills will affect the long-term physical stability of this subsurface feature as well as the potential ingress of moisture and contaminant release. The hydraulic and geochemical behavior of closed tank systems need to be assessed from a conceptual standpoint and characterized to the extent that system components and accessibility allow. Models are needed to predict future performance and release of contamination from the component materials and integrated structures.

Approach: Iterative activities between engineering and science organizations working on grout stabilization of the SSTs will be required to establish a conceptual hydrophysical model of a closed tank that can be sequentially parameterized through estimation/bracketing procedures and direct measurement. A reductionistic approach will be used to measure first-order hydraulic and geochemical parameters on primary system components such as grout, grouted residual tank waste, or concrete shell materials as they become available. Individual components will be assembled within an engineering-based simulator to estimate water and contaminant fluxes that evolve over the long term.

Benefit: Closure decisions will rely heavily on system-scale computer models (e.g., the tank farm with associated covers and other mitigative structures or features) to forecast future behavior. A central component of this system will be isolated residual tank waste that could potentially function as a longterm contaminant source in the future if certain conditions are allowed to develop. Defensible estimates and characterizations of the hydraulic and geochemical properties of the stabilized residual waste form will allow such forecasts in association with other information.

Schedule: The schedule for this proposed area of research will be from 2014 to 2019. Characterization of waste form materials will be performed as they become available.

\subsection{Improved Surface Barriers}

Objective: Surface barriers will be installed as part of tank-farm closure. These will be some of the most sophisticated and demanding structures of their kind ever constructed world-wide. A prototype barrier over the 216-B-57 crib (immediately north of the BY tank farm) has been monitored since it was constructed in 1994, and other barrier designs have been configured for different Hanford applications and operational periods. Tank-farm closure barriers are likely to have stringent requirements with respect to recharge, design life, and post design-life performance that have not yet been specified.

Approach: Significant technology development will be necessary to meet these requirements. Historical water balance data for the prototype barrier will be integrated with new and extensive geophysical measurements beneath the barrier and interpreted with state-of-the-art vadose zone hydrologic models to develop the best possible understanding of its performance vis-à-vis anticipated requirements for tankfarm closure. These activities will yield improved, new designs for barrier materials, configurations, layering, slope, etc., that will require experimental confirmation as well as the identification of technical or science needs that require resolution for final implementation.

Benefit: Barriers with credible design and realistic documentations of performance will provide confidence that residual tank wastes are sufficiently isolated in the subsurface to prevent future impacts to groundwater. 
Schedule: The schedule for this proposed area of research will be from 2011 to 2015. Surface barrier technologies will be needed for tank-farm closure, scheduled to occur for C Farm in 2019.

\subsection{Improved Computer Codes}

Objective: A variety of computer codes will be improved and parameterized as part of research leading to successful tank-farm closure. These will include ones describing contaminant geochemical and biogeochemical interactions and transformations; moisture migration, barrier performance, and reactive transport; residual waste evolution and source term release; and relationships between geophysical measurements, hydrologic properties, and porewater compositions. These codes, which may begin as research tools to aid in interpreting field or experimental observations, may progress to the level that they become essential components of scientifically rigorous performance assessment. There is a critical need to transfer specific models and their databases to tank-farm contractors, remediation specialists, and closure engineers to enable the best possible performance assessments and closure decisions.

Approach: Science-based computer codes that have high potential to be used for tank-farm closure assessments will be identified early in the closure processes. Research will be performed to populate the candidate models with the most current descriptions of important controlling processes as well as site, waste, sediment, and contaminant-specific parameters. The models and their key assumptions and fundamental parameters will be subjected to validation studies using databases of laboratory or field experiments/studies that are appropriate models of the application and that span appropriate parameter space for planned scenarios. Criteria will be established for acceptable validation by peer review. Validated codes will be subjected to quality assurance/quality control (QA/QC) evaluation and configuration control before transfer and use in the regulatory arena.

Benefit: The use of validated, scientifically based models and the most current and rigorous databases and process-descriptive parameters will reduce the uncertainty in tank-farm assessments and improve the acceptance closure decisions.

Schedule: The schedule for this proposed area of research will be from 2012 to 2019. Improvements in computer codes are ongoing and will be used to support performance assessments later in Phase 2. Other agencies, such as the DOE's SC, are investing in research to advance subsurface computational capabilities, and the results of that research will be available in this time frame. 


\subsection{Integration with Other Hanford Efforts}

The Hanford Site is large and complex with a number of research activities having different goals and objectives supported by various Hanford contractors and DOE offices. Applied research is generally performed by remediation contractors using PNNL and a variety of others from the university, national laboratory, and consulting engineering community. The activities of DOE Headquarters are funded through the DOE Office of Engineering and Technology (EM-20) and the DOE's Office of Science (SC).

All of the research activities have components that are relevant to tank-farm closure and can be leveraged to support the tank-farm mission. This S\&T roadmap has been formulated to complement and leverage important Hanford and national research activities. Progress achieved in each of these programmatic investments will be tracked by the S\&T effort. In some cases, the research results will be integrated directly into scientific projects for Phase 2, similar to what was done during Phase 1 for the Field Investigation Reports for the S-SX, B-BX-BY, and T-TX-TY tank farms.

\subsection{Contractor-Directed Research and Development Activities}

The Tank Operations Contractor (TOC) is responsible for retrieving waste stored in 177 underground storage tanks at the Hanford Site, consisting of 149 SSTs and 28 double-shell tanks. The overall mission is to empty the tanks and complete actions leading to tank-farm closure. Associated with the tank-farm retrieval activities will be leak detection technologies described in Section 6.4. The TOC is responsible for providing waste feed to and from the Waste Treatment Plant. The Waste Treatment Plant contractor, Bechtel National, Inc., is designing and constructing a treatment plant to vitrify tank waste by blending it with molten glass and placing it in stainless steel canisters. The TOC is also responsible for developing and implementing supplemental technologies that can be used to treat the remaining low-activity waste. A roadmap is being prepared in parallel to address the S\&T development related needs of secondary waste treatment. The S\&T activities associated with tank-farm closure will be linked with this roadmap effort.

The Central Plateau Contractor (CPC) is responsible for a broad range of activities, including dismantling former nuclear processing facilities, retrieving and processing transuranic waste for offsite shipment, maintaining the site's infrastructure and providing site services, monitoring and cleaning up contaminated waste sites outside of tank farms, and remediating groundwater. Through the Soil and Groundwater Remediation Project, the CPC is funding a number of activities that are relevant to tank-farm closure. The CPC is focused on characterizing and remediating groundwater contamination and high-risk waste sites that pose risk to groundwater. Some of these waste sites are adjacent to tank farms that will be closed, and associated activities require integration. To this end, the contractors have formed multiproject teams to integrate tank farm and waste site investigations. Integration extends to drilling and sampling activities as well as SGE surveys. In addition, field characterization is being performed to provide "ground truth" data for HRR that has been performed in the BC Cribs and Trenches Area. Because the contaminant of interest for the HRR survey in this region is ${ }^{99} \mathrm{Tc}$, the results of this investigation and research will be directly relevant to tank-farm closure.

The CPC provides funding for S\&T research and technical integration activities, including laboratory and field investigations, remediation and decision support, and technical integration (database development 
and modeling support). The recent focus of this activity has been to conduct laboratory-scale research to develop data for improved conceptual and numerical models of uranium fate and reactive transport within the vadose zone and groundwater at the 300 Area and ${ }^{90} \mathrm{Sr}$ in the $100-\mathrm{N}$ Area. The research supports long-term predictions of these plumes to explain their persistence and develop new remediation approaches. Field investigations have focused on assessing the migration of uranium in the 300 Area and testing methods to measure flux into the Columbia River. These activities are important to tank-farm closure because they contribute to the overall understanding of the Hanford subsurface and the behavior of specific contaminants such as $\mathrm{U},{ }^{99} \mathrm{Tc}$, and $\mathrm{Cr}$. The $\mathrm{CPC}$ also provides funding for modeling of a research nature with the objective of building, testing, and integrating mechanistic conceptual process models into reactive transport simulations. Recent work has focused on the 300 Area uranium plume and development of field-scale reactive transport models based on data and process models developed through laboratory investigations. Other research-oriented modeling has been performed to evaluate contaminant transport in the BC Cribs and Trenches site to assist with remediation design and testing of new subroutines in Subsurface Transport Over Multiple Phases (STOMP) for predicting carbon tetrachloride fate and transport in the vadose zone.

The CPC is developing a treatability test plan to evaluate remediation approaches for deep vadose zone contamination. The plan has been generated in draft form and circulated for review and comment. The plan involves performing a field evaluation of the soil desiccation technology in the deep vadose zone at the BC Cribs and Trenches. Laboratory-scale soil desiccation experiments have been performed to support the design of the desiccation system. These experiments provide input parameters to be able to model soil desiccation. The STOMP code has been modified to be able to simulate soil desiccation field applications.

Through the Remediation Decision support project, the CPC maintains technical baseline information to support the development of defensible conceptual models and to address key cross-cutting technical issues and data gaps that affect remedial decisions. This support has included assembly/revision of a number of data catalogs and data packages for Hanford assessments and waste site operable unit characterization and remediation decisions. The project is also responsible for the current Hanford Soil Inventory Model, which computes waste discharges composed of 75 analytes at 377 Hanford waste sites (liquid disposal, unplanned releases, and tank-farm leaks) over an operational period of approximately 50 years.

\subsection{DOE-Directed Research and Development Activities}

The DOE Office of Engineering and Technology (EM-20) developed an engineering and technology roadmap (DOE EM, 2008) to reduce technical risk and uncertainty in the EM Program. The roadmap was prepared to identify technology gaps that exist in the current program and devise a strategy to fill them. The Waste Processing portion of the roadmap identifies a number of initiatives for improved waste storage technologies; reliable and efficient waste retrieval technologies; enhanced tank closure processes, including methods for characterization and stabilization of residual tank wastes, improved methods and materials to efficiently close complicated ancillary systems, and integrated cleaning, closure, and capping demonstrations; next generation pre-treatment technologies; and enhanced stabilization technologies, including advanced glass formulations and supplemental treatment methodologies. The Groundwater and Soil Remediation portion of the roadmap includes initiatives for improved sampling and characterization strategies, advanced predictive capabilities, and enhanced remediation methods. 
Several of the EM-20 Groundwater and Soil Remediation initiatives are closely linked with Hanford Site problems and are relevant to tank-farm closure, namely the advanced predictive capabilities, and in situ treatment systems for metals and radionuclides. The advanced predictive capabilities project is focused on providing methods for translating scientific results into conceptual and numerical models for complex sites, developing methodologies for assessing alternative conceptual models that address uncertainty, providing protocols for selecting and implementing numerical models, and providing guidance for characterizing complex sites to obtain data for developing alternative conceptual and numerical models. The project developing in situ treatment systems for metals and radionuclides is focused on applying emerging scientific and technical knowledge to enhance the understanding of contaminant behavior, introduce innovative remediation approaches based on applied science, and integrate with field activities for ${ }^{99} \mathrm{Tc}$ at the BC Cribs and Trenches Site at Hanford. These projects are just underway in FY 2008 and are initiating project activities that link with Hanford Site efforts.

The Environmental Remediation Sciences Division (ERSD) within DOE's Office of Biological and Environmental Research (BER) in DOE's SC supports a major research program (Environmental Remediation Science Program, ERSP) containing select projects that are relevant to tank-farm closure. Research is focused on contaminant fate and transport processes, (geochemical and microbiologic) geophysical approaches to characterize the subsurface, and the development of improved reactive transport models for long-term calculations of contaminant migration. The ERSP supports two Hanford projects at PNNL including:

- a field study at Hanford's 300 A uranium plume focused on understanding and modeling the role of mass transfer in regulating seasonal and long-term uranium concentration trends in groundwater and the effectiveness of remediation (Hanford Integrated Field Challenge, IFC)

- a scientific focus area program (SFA) involving 11 individual laboratory and field projects focused on fundamental processes controlling subsurface migration of $\mathrm{U}, \mathrm{Tc}$, and $\mathrm{Pu}$ as well as characterizing Hanford subsurface microbial ecology.

Linked with these ERSP activities are two modeling projects from DOE's SC, Advanced Scientific Computing Research (ASCR) Program, that emphasize the development of new computational approaches for modeling subsurface processes.

Phase 2 research attempts linkage with DOE's SC program to strengthen the scientific and modeling program associated with tank-farm closure. For example, it relies on the ERSP for improved biogeochemical process models of contaminant reaction and retardation, and new generation microscopies and spectroscopies to determine the chemical speciation and mineralogic association of contaminants in both residual tank waste and subsurface materials. Significant upgrades to flow and reactive transport simulators and advanced numeric platforms for large subsurface inversion problems associated with geophysical measurements and reactive transport simulations are anticipated from ASCR research. 


\subsection{References}

DOE Environmental Management (DOE EM). 2008. Engineering and Technology Roadmap; Reducing Technical Risk and Uncertainty in the EM Program. Washington, D.C.

DOE Office of River Protection (DOE ORP). 2008. RCRA Facility Investigation Report for Hanford Single-Shell Tank Waste Management Areas. DOE/ORP-2008-01, Rev. 0, Tier 1, 2, and 3, Richland, Washington.

DOE Office of River Projection (DOE ORP). 2005. Initial Single-Shell Tank System Performance Assessment for the Hanford Site. DOE/ORP-2005-01, Rev. 0, Richland, Washington.

Mann FM, M Connelly, DA Myers, TE Jones, R Khaleel, MI Wood, MD Freshley, and RJ Serne. 2007. An Evaluation of Hanford Site Tank Farm Subsurface Contamination. FY 2007, RPP-33441, CH2M HILL Hanford Group, Inc., Richland, Washington. 


\section{Distribution}

No. of

Copies

OFFSITE

3 U.S. Department of Energy, Office of Science, Environmental Remediation Sciences

Division, SC-23,4

19901 Germantown Road

Germantown, MD 20874-1290

Attn: Robert T. Anderson

James M. Kuperburg

David Lesmes

2 U.S. Department of Energy, Environmental Management, Office of Engineering and Technology, EM-22-CL

19901 Germantown Road

Germantown, MD 20874-1290

Attn: Vincent Adams

Grover M. Chamberlain, Jr.

1 Mark Gilbertson

Deputy Assistant Secretary for Engineering and Technology

DOE EM Office of Engineering and

Technology

1000 Independence Avenue

Forrestal Building, EM-20

Washington, D.C. 20585-0121
No. of

Copies

ONSITE

8 CH2M HILL Hanford Group

Mike Connelly H6-03

SJ Eberlein (1) H6-03

JG Field H6-03

JA Lowe H6-03

Fred Mann (2) H6-03

SG McKinney T6-02

DA Myers H6-03

HA Sydnor H6-03

2 Energy Solutions

DJ Moak G1-62

KD Reynolds G1-62

1 Fluor Hanford, Inc.

MI Wood H8-44

$1 \quad$ Pacific Northwest Geophysics

RK Price

G1-62

$1 \quad \underline{\text { Stoller }}$

Rick McCain B2-62

$1 \quad 3$ Rivers Scientific

RR Randall G1-62

Distr. 1 
No. of

Copies

OFFSITE
No. of

Copies

\section{ONSITE}

12 Pacific Northwest National Laboratory

$\begin{array}{ll}\text { TJ Brouns } & \text { K9-69 } \\ \text { CF Brown } & \text { P7-22 } \\ \text { KJ Cantrell } & \text { K6-81 } \\ \text { PE Dresel } & \text { K6-96 } \\ \text { MJ Fayer } & \text { K9-33 } \\ \text { FL Freedman } & \text { K9-33 } \\ \text { MD Freshley (5) } & \text { K9-33 } \\ \text { RJ Serne } & \text { P7-22 } \\ \text { TL Stewart } & \text { K6-84 } \\ \text { MB Triplett } & \text { H6-60 } \\ \text { SB Yabusaki } & \text { K9-33 } \\ \text { JM Zachara (5) } & \text { K8-96 }\end{array}$

Distr. 2 